\title{
Integrated reporting quality and BoD characteristics: an empirical analysis
}

\author{
Lucrezia Songini $^{1}$ (D) Anna Pistoni ${ }^{2} \cdot$ Patrizia Tettamanzi $^{3} \cdot$ Fabrizio Fratini $^{3}$. \\ Valentina Minutiello ${ }^{3}$
}

Accepted: 4 March 2021 / Published online: 22 March 2021

(c) The Author(s) 2021

\begin{abstract}
The amount of literature on IR has grown over the last few years, but while particular attention has been paid to the variables that can play a role in IR adoption, IR quality and its determinants are still the subject of debate. The main determinants of IR quality outlined by the literature are firm size, industry, national context, firm performance, assurance, and to a lesser extent, corporate governance and company ownership structure. However, previous studies have usually reached conflicting results, thus not providing shared conclusions.

This paper aims to understand the impact of the Board of Directors' features on IR quality, evaluated in terms of the degree of compliance between IR content and the guidelines suggested in the IR framework presented by IIRC. The Board's characteristics considered are size, composition and diversity with regard to board members' gender, age and level of education.

53 companies were taken into consideration from 2013 to 2016 for a total number of 212 integrated reports. Five research hypotheses were developed. Research findings highlight that IR quality is positively associated with the level of education of board members, and negatively with the presence of women. Moreover, among control variables, profitability (positive relation) and leverage (negative relation) are relevant determinants. Our research findings support the idea that the "quality" of the board members matters more than their "quantity" in increasing IR quality, and that diversity in the board is more relevant than diversity of the board.
\end{abstract}

Keywords Integrated reporting · Quality · Board of Directors · Education · Gender · Age

Lucrezia Songini

lucrezia.songini@uniupo.it

Extended author information available on the last page of the article 


\section{Introduction}

Integrated Reporting (IR) is one of the most recent attempts to expand non-financial reporting and accountability, to include the social and environmental impacts of business (Melloni et al. 2017; Stubbs \& Higgins, 2018). This reporting framework brings together material information on an organization's strategy, governance, performance and prospects in a way that reflects the firm's value creation process.

Although the literature on IR has grown over the last few years, it remains fragmented (Dumay et al. 2016). Most attention has been paid to the variables which can play a role in IR adoption (Frías-Aceituno et al. 2012, 2013; Perego et al. 2016; Dumay et al. 2017; Velte \& Stawinoga, 2017; Rinaldi et al. 2018), although a growing body of literature has more recently focused on the determinants of IR quality. Firm size, industry, national context, firm performance (profitability and leverage), assurance, companies' ownership structure and corporate governance mechanisms are the most significant drivers of IR quality identified by researchers. In terms of governance the Board of Directors' characteristics are relevant to good IR practices, since the board is responsible for representing and defending different stakeholders' interests (Healy, 2002; Perrini, 2006). An effective board can mitigate managerial opportunism and provide a more comprehensive view of stakeholders' interests, which may result in higher disclosure quality (Frías-Aceituno et al. 2012; García-Sanchez et al. 2019).

Some studies have analyzed the role played by the board in voluntary disclosure processes, with reference, for example, to size and composition, distribution of gender, percentage of independent members, and education. Howeer, findings do not always converge.

This paper aims to analyze the role and the impact of the board's characteristics on IR quality in order to fill the research gaps suggested by Perego et al. (2016) and Vitolla et al. (2020a) concerning the need for more empirical studies on the quality of the disclosure offered by IR and its determinants. In order to solve some of the limitations of previous contributions in the research field (Vitolla et al. 2020a), we decided to conduct a longitudinal analysis to identify some possible trends over time.

Finally, this study enriches the existing literature by providing new insights into the determinants of IR quality thanks to the analysis of a sample made up of international companies from different sectors. IR quality is evaluated in terms of compliance between IR content and the guidelines suggested in the IR framework developed by the International Integrated Reporting Council (IIRC). We referred in particular to the Content area of the Integrated Reporting Scoreboard (IRS), proposed by Pistoni et al. (2018).

The board characteristics considered are size, composition (executive versus nonexecutive directors) and diversity (board members' gender, age and level of education).

Integrated reports published by 53 companies from 2013 to 2016 were taken into consideration, for a total number of 212 documents. We specifically selected 
2013 as the starting point as it is the year the IIRC issued both the "Consultation draft on the International $<$ IR $>$ framework" and the "International $<$ IR $>$ framework". This led us to assume that reports published since 2013 are more likely to respect the IR framework. Five research hypotheses were developed. Random Effect panel regression analysis was used to verify the hypotheses controlling for endogeneity issues through lagged firm specific explanatory variables.

Research findings highlight that IR quality is positively associated with the level of education of members and negatively with the presence of women. Profitability (positive relation), and leverage (negative relation) are relevant determinants among control variables. If we exclude companies operating in South Africa, where the adoption of IR is mandatory, firm size (negative relation), when not operating in an Anglo-Saxon country or in a manufacturing industry, are also significant determinants of IR quality.

This paper is structured as follows: in Section 1 the most relevant literature is presented; in Section 2 the research methodology is described; Section 3 briefly discusses preliminary findings, and finally Section 4 outlines conclusions.

\section{Literature review}

In this section the main definitions of and methods to assess IR quality, proposed by the literature, are presented. Then, the main studies on board characteristics and their impacts on both disclosure and IR quality are discussed. In particular, studies concerning three main board characteristics are outlined: board size, board composition and board diversity.

\subsection{IR quality assessment}

Previous literature focused on the quality of both the whole report and some specific aspects of the IR document. Different facets of IR quality have been analysed by authors, using different methods to assess the quality. Most authors applied a content analysis methodology, using a wide range of items and scoring systems.

With regard to materiality disclosure quality, Gerwanski et al. (2019: 6) used content analysis to "construct an original, hand-collected MDQ score". Fasan and Mio (2017: 295) applying two different variables: "Word count of the terms 'material'/'materiality' divided by the number of pages of the report (MaterialityWC) ... and Relevance of materiality disclosure (Relevance)". Kiliç and Kuzey (2018) developed a forward-looking disclosure index (FLDI) through a content analysis approach. Melloni et al. (2016) performed a manual content analysis to assess the tone of the business model (BM) disclosure.

Havlová (2015), focusing on how reporting changed after the adoption of IR, assessed the degree of integrated adoption, referring to a five-point scale that considers whether the company follows the IIRC framework's requirements and discloses all required information. Stent and Dowler (2015) provided an assessment of corporate reporting changes after the birth of IR, applying a checklist based on the 
content elements of the IR framework, with some reference also to the fundamental concepts and some guiding principles (e.g. capitals, and the concept of value creation). They developed a binary scoring system to assess the coverage of an IR requirement, with a checklist considering the following items: organizational overview and business model, operating context, strategic objectives, and strategies to achieve them, governance structure, performance, future outlook, and assurance. Lipunga (2015) studied the IR level in developing countries, applying content analysis to a disclosure framework obtained from the integration of the lists of items used by du Toit et al. (2014) and Abeysekera (2013). The value of " 1 " was assigned to the integrated reports when an item of the disclosure framework was present and " 0 " otherwise.

Pistoni et al. (2018) proposed the Integrated Reporting Scoreboard (IRS), to assess IR quality in terms of compliance between IR content and the IIRC's framework guidelines. Following Hammond and Miles (2004), four disclosure areas (Background area, Assurance and reliability area, Content area and Form area) were defined and articulated into twenty-three variables to identify the IRS. The Content area considers eight elements (organizational overview and external environment, business model, risks and opportunities, strategy and resource allocation, governance, performance, outlook, and basis of presentation) and two fundamental concepts (Capitals and Value creation process), which constitute the main aspects of the IIRC's framework. Pistoni et al. (2018) proposed the use of a scoring system which assigns a score between 0 (absence) and 5 (very high quality) to each of the eight elements and two fundamental concepts, considering the following aspects: how the topic is presented, whether its description is exhaustive and whether it refers explicitly to the IR guiding principles. As it considers all main aspects and principles of the IIRC's framework, applying an assessment methodology consistent with that used by previous relevant studies on the assessment of disclosure quality (Hammond $\&$ Miles, 2004), the Integrated Reporting Scoreboard (IRS) can be considered one of the most complete frameworks recently proposed by the literature.

\subsection{Board characteristics and the quality of disclosure and IR}

The relationship between corporate governance and the disclosure practices of companies has been widely explored (Adams, 2002; Ajinkya et al. 2005; Cerbioni \& Parbonetti, 2007; Eng \& Mak, 2003; Healy \& Palepu, 2001; Qu et al. 2015; Ricart et al. 2005).

In particular, the role played by the board appears to be crucial (Fiori et al. 2016), since it is responsible for representing and defending the different stakeholders' interests (Frías-Aceituno et al. 2012). The impact of board characteristics has been widely recognized as a relevant determinant of a company's voluntary disclosure processes and mechanisms, affecting both their adoption and the quality and extension of information provided. As the board is the main decision-making organism, it is responsible for safeguarding the different stakeholder interests also by stimulating a wide and complete information disclosure to deter managerial opportunism (Amran \& Haniffa, 2011; Frías-Aceituno et al. 2012; Richardson \& Welker, 2001). 
Different studies have analyzed the relation between the tone and quality of disclosure and certain board characteristics, such as size (number of directors) and structure (the percentage and role of independent directors) (Klein, 2002; Xie et al. 2003). Melloni et al. (2016) found a positive relationship between the quality of disclosure and strong governance in terms of a low number of members and a high percentage of independent members in governance bodies. Other scholars provided empirical evidence showing that board size enhances a company's disclosure and its quality (Akhtaruddin et al. 2009; Qu et al. 2015), as well as pointing to board gender diversity as having a positive impact on voluntary disclosure of holistic information (Frías-Aceituno et al. 2012).

Definitive results are not provided by the literature examining the impact of board activity on disclosure quality. Some studies highlighted how frequent meetings of board members can contribute to improving their supervisory functions, reducing the risk of corporate earnings manipulation as well as of problems due to asymmetric information in the quarterly earnings announcements (Kanagaretnam et al. 2007). On the other hand, other scholars (Karamanou \& Vafeas, 2005) concluded that there is no relation between board activities and the quality of financial information disclosed.

With specific regard to the literature on IR, while it has been suggested that board characteristics may be among the variables determining the adoption of IR, the literature focusing on the relationship between the board and IR quality is quite scarce. Vitolla et al. (2020a, 2020b) have recently found that some board characteristics, such as the presence of female directors and nonexecutive members, and board size, increase IR quality (Vitolla et al. 2020a) and Intellectual Capital Disclosure quality within IR (Vitolla et al. 2020b).

In the light of this evidence, in the following paragraphs the main previous studies focused on the characteristics of the board and their impact on both disclosure quality and IR quality are presented. We analyzed the relationship between the board of directors and IR quality by examining three different characteristics of the board: board size, board composition and board diversity. Following the empirical analysis by Frías-Aceituno et al. (2012), demonstrating that board activity is not correlated with the probability of a company producing an IR we excluded this variable from our analysis.

\subsubsection{Board Size}

Board size is defined as the total number of executive and nonexecutive members on the board (Wang \& Hussainey, 2013). Itis often viewed as one of the major determinants of board effectiveness (Amran et al. 2014). Wang and Hussainey (2013), for example, found that a large board is generally less effective than a smaller board because of communication and coordination related problems.

With specific reference to the relationship between board size and disclosure quality, the corporate governance literature provides different arguments that may lead to different expectations. Notwithstanding its relevance, there is, in fact, no full consensus in the prior studies regarding the relationship between board size and company disclosure. On one hand, several studies argued that small boards are more 
effective at monitoring than large boards because larger boards will experience more difficulties in reaching an agreement. For example, concerning materiality disclosure, larger boards may have difficulties in obtaining consent on the identification of relevant issues and this therefore may lead to poorer materiality disclosure (Fasan \& Mio, 2017). Similarly, Prado-Lorenzo and García-Sánchez (2010) found a negative relationship between board size and information quality disclosure. Alnabsha et al. (2018) observed a negative relationship between board size and overall corporate disclosure level. According to the authors, this is due to the fact that larger boards may act inefficiently because of the lack of communication and coordination (Said et al. 2009). Therefore, while the monitoring capacity of the board increases with more directors, this benefit may be outweighed by costs related to ineffective communication and slow decision-making (John \& Senbet, 1998).

On the other hand, Akhtaruddin et al. (2009) stated that as the board is an organism devoted to reducing managerial opportunism, a large board is expected to be a more effective governance mechanism enhancing transparency and voluntary company disclosures. Moreover, Frías-Aceituno et al. (2013) suggested that on larger boards there are more likely to be experienced directors with different backgrounds and this enhances the integration of various reports. Qu et al. (2015) found a significant and positive influence of board size on the quality of information disclosure. Similarly, Pearce and Zahra (1992), Dalton et al. (1999), Wang and Hussainey (2013) reported a positive relationship between the number of directors and the relevance and integration of corporate information provided; they also found a positive association with the voluntary forward-looking statement. Alfraih (2018) confirmed the positive association between board size and the disclosure quality with specific reference to the level of intellectual capital disclosure. Studying the company's level of information integration, Busco et al. (2019) found that bigger board size has a positive impact on the Integration Reporting Index. In the specific case of IR, Vitolla et al. (2020a, 2020b) confirmed this positive association.

According to stakeholder theory, the positive relation between board size and disclosure may be due to the greater diversity among members, which includes financial expertise and experience (Elzahar \& Hussainey, 2012; Wang \& Hussainey, 2013). With specific regard to IR, Frías-Aceituno et al. (2012) argued that, due to its own purposes and nature, IR requires the involvement of board members with different types of expertise, in order to inform a wider range of stakeholders and provide information on different issues and themes. Moreover, according to Aggarwal and Nanda (2004), larger boards are more likely to address a wider range of stakeholders, since different board members represent different stakeholder categories. Finally, Fasan and Mio (2017) suggested that larger boards are correlated with a higher level of materiality disclosure, because they have more expertise, represent a wider range of stakeholders and are more likely to foster social performance.

\subsubsection{Board composition}

Boards are generally composed of executive and nonexecutive (independent) members. Actually, board composition has been defined as "the percentage of independent directors to the total number of directors" (Hossain \& Reaz, 2007: 279). 
According to agency theory (Akhtaruddin et al. 2009), board composition can determine the effectiveness of corporate governance mechanisms in reducing agency problems. Indeed, from an agency perspective, boards with a higher proportion of independent directors are more effective in monitoring and controlling management and more successful in directing management toward long-term value (Jizi et al. 2014). Overall, the larger the proportion of nonexecutive directors on the board, the more effective the monitoring role on managerial opportunism will be (Fiori et al. 2016; Weir \& Laing, 2003). This is mainly due to the fact that the remuneration of independent directors is not related to a firm's short-term financial performance, unlike the remuneration of other members of the board (Jizi et al. 2014). The potential dis-alignment between independent directors and company management could lead to an increase in both the quality and quantity of voluntary disclosure (Fama \& Jensen, 1983; Michelon \& Parbonetti, 2012). A majority of independent directors may have the power to force management to disclose more information (Wang \& Hussainey, 2013).

In this field of study, prior literature again shows different findings (Kakabadse et al. 2010).

Several authors found the percentage of independent directors to be insignificant on disclosures (Al-Najjar \& Abed, 2014; Elzahar \& Hussainey, 2012; GarcíaSánchez et.al., 2011; O’Sullivan et al. 2008; Uyar \& Kiliç, 2012), suggesting different reasons for this. On one hand, the effectiveness of independent members may depend on the institutional systems and business cultures in which a company operates (Kakabadse et al. 2010); for instance, independent members are not in strong positions on Chinese boards, typically dominated by insiders (Kakabadse et al. 2010). On the other hand, the low level of association between board independence and a firm's disclosure may be due to a restricted role of independent members in the reporting practices of the organization, as they are not directly involved in company operations (Amran \& Manaf, 2014). Prado-Lorenzo and García-Sánchez (2010) and Alnabsha et al. (2018) found a negative relationship between the board composition in terms of the number of independent members and the overall corporate disclosure level.

Some other authors, however, argue that board independence is positively related with disclosure in general (Prado-Lorenzo et al. 2010; Cheng \& Courtenay, 2006), or with disclosure on earnings forecast (Wang \& Hussainey, 2013), with more precise sales forecasts (Qu et al. 2015), or with forward-looking disclosures (Liu, 2015). According to previous literature regarding earnings management, more independent boards are expected to significantly reduce earnings management and therefore increase the quality of the information disclosed (Bar-Yosef \& Prencipe, 2009). In the same vein, board independence would positively impact accountability and thus increase the extent of company disclosure (Rao \& Tilt, 2016). Alfraih (2018) confirmed the positive association between the number of external (nonexecutive and independent) directors and the level of intellectual capital disclosure. Dah et al. (2018) showed that the presence of independent members increases social disclosure and that this leads also to a positive influence on firm performance.

Finally, in the context of IR, Fasan and Mio (2017) argued that more independent boards will positively influence the quality of company disclosure (and thus of IR) 
by fostering materiality disclosure. Independent directors place a greater focus on monitoring firm conduct, together with the willingness to improve firm reputation (Fama \& Jensen, 1983). This attitude can improve the quality of company disclosure. Moreover, since they are less affected by competitors than executive directors are (Prado-Lorenzo \& García-Sánchez, 2010), independent members are more interested in satisfying new information needs (García-Sanchez et al. 2011). This result is also confirmed by Vitolla et al. (2020a, 2020b).

\subsubsection{Board diversity}

Following the classification provided by Hafsi and Turgut (2013), we should refer mainly to the concept of diversity in the board, meaning differences in directors' characteristics, rather than diversity of the board, related to differences in the board's formal structure. Board diversity, therefore, refers to board members with different characteristics in terms of gender, age, race and ethnicity, personality and learning style, educational background and knowledge, expertise and skills (Coffey \& Wang, 1998; Haniffa \& Cooke, 2005; Van der Walt \& Ingley, 2003).

According to Frías-Aceituno et al. (2012), board diversity favors problem-solving, increases leadership effectiveness and improves global relationships. Board members with different characteristics determine a wide range of knowledge and skills that bring different perspectives and ideas to the board (Harjoto et al. 2015). Carter et al. (2003) suggested that board diversity enhances board independence, because directors with diverse gender, ethnicity, experience and backgrounds will ask questions that might not asked by directors with more similar backgrounds. For instance, gender diversity may bring different perspectives and opinions to board discussions, and therefore lead the board to make better decisions (Barako \& Brown, 2008; Bear et al. 2010).

Harjoto et al. (2015) studied the relationship between different dimensions of board diversity (gender, outside directorship, tenure, race, age, power and expertise) and corporate social responsibility in the USA. Consistently with stakeholder theory, they found that board diversity increases a company's ability to satisfy the needs of its stakeholders. Gerwanski et al. (2019) proposed that greater diversity of the board can be associated with better stakeholder interaction and greater reporting transparency.

The Upper Echelons theory, proposed by Hambrick and Mason (1984), provides a useful theoretical framework to explain the impacts of board diversity; it states that organizational outcomes and performance are influenced by background characteristics of the management team, in particular by feelings, values, and beliefs (Bantel \& Jackson, 1989; Carpenter et al. 2004; Hambrick \& Mason, 1984; Park \& Gould, 2017). This effect depends on the limited capacity of humans to process information, implying that decisions are determined by personal characteristics and tendencies (Oppong, 2014). Thus, the executives' process of decision making is determined by their personal interpretation of reality, which, in turn, is influenced by their cognitive processes, beliefs, personality traits and ethical norms of conduct (Abatecola \& Cristofaro, 2018; Hambrick \& Mason, 1984; Hambrick, 2007). 
In terms of personal characteristics, previous studies considered a series of demographic variables such as age, functional background, career experiences, education, gender and socioeconomic background (Carpenter et al. 2004; Hambrick \& Mason, 1984; Sparrow, 1994). The stream of research on Upper Echelons theory started out by focusing on top management teams and on chief executive officers (CEOs) but more recently has been extended to the Board of Directors insofar as the knowledge, skills and expertise of board members affect strategic decision-making, business performance and sustainability (Åberg \& Torchia, 2019; Horner, 2009; Shahab et al. 2018). For instance, regarding board diversity in terms of gender, some studies have argued that the presence of female directors is related with a better environmental and social performance (Hassan et al. 2015, 2017; Orazalin \& Baydauletov, 2020; Post et al. 2015) and, more in general, with overall better firm performance (Adams $\&$ Ferreira, 2009). Other studies found that the presence of women on the board is positively related to firms' environmental innovation (Hyun et al. 2016; Isidro \& Sobral, 2015; Liao et al. 2019). Some authors suggested that board members' knowledge and experience lead to better decisions and consequently to strategic change (Åberg \& Torchia, 2019; Haynes \& Hillman, 2010; Westphal \& Fredrickson, 2001). Hambrick and Mason (1984) claimed that organizations guided by young executives are more risk-oriented, while other studies showed that managerial youth is associated with corporate growth (Child, 1974; Hart \& Mellons, 1970). Other contributions showed that the level of education is positively related to innovation reception (Becker, 1970; Kimberly \& Evanisko, 1981; Rogers \& Shoemaker, 1971).

With specific reference to corporate disclosure, some scholars (Abeysekera, 2010; Guthrie \& Parker, 1990; Haniffa \& Cooke, 2005; McGuinnesset al., 2017; Rupley et al. 2012) found that board diversity has a positive impact on various forms of corporate social disclosure. Alfiero et al. (2018) indicated a positive relationship between the board and its composition, in terms of gender and size, and the choice to adopt IR, while national diversity and average age are negatively related.

Gender diversity represents one of the key variables of board characteristics studied in empirical research. According to Bear et al. (2010), women in managerial roles often stimulate more participative communication between board members; hence, gender diverse boards may better manage the needs of different groups of stakeholders. Several studies demonstrate how the presence of women at the senior management level positively affects company behavior and raises the effectiveness of board decisions (Adams \& Ferreira, 2009). One reason for this kind of result is that female directors apply ethical criteria (as a wife and/or a mother) that are different from those of their male colleagues (Kessler-Harris, 1990). This is often associated with increased information transparency, primarily related to sustainability issues (Barako \& Brown, 2008; Frías-Aceituno et al. 2012; Prado-Lorenzo \& García-Sánchez, 2010; Rao \& Tilt, 2016) and reputation (Bear et al. 2010). Consequently, an increase in the board gender diversity may lead to a better assessment of the needs of diverse stakeholders (Fiori et al. 2016; Frías-Aceituno et al. 2012). Female directors are seen to be more participative (Eagly et al. 2003), democratic (Eagly \& Johnson, 1990) and communal than men (Rudman \& Glick, 2001). The main reason for this can be traced to the fact that female directors are more likely than men to have a wide range of knowledge and skills and a higher level 
of charitable interaction (Wang \& Coffey, 1992; Williams, 2003), allowing them to promote different perspectives (Harjoto et al. 2015; Hillman et al. 2002) and more favorable work environments (Bernardi et al. 2006; Johnson \& Greening, 1999).

Previous corporate governance research provided a variety of studies that reveal a positive impact of board gender diversity on financial and non-financial reporting (e.g. Haniffa \& Cooke, 2005; Harjoto et al. 2015). Fernandez-Feijoo et al. (2014) demonstrated that the degree of gender diversity affects board decisions, which in turn determine the extent of non-financial reporting. Frías-Aceituno et al. (2012) noted that board gender diversity has a positive impact on the voluntary disclosure of holistic information. Moreover, the representation of women on the board has been shown to positively affect environmental disclosure quality (Rupley et al. 2012). Gerwanski et al. (2019), and Rao and Tilt (2016) found a positive association between board gender diversity and materiality quality disclosure. Fuente et al. (2017) and Tamimi and Sebastianelli (2017) highlighted the positive influence of female directors on the disclosure of socio-environmental information.

With specific regard to IR, Kiliç and Kuzey (2018) showed that board gender diversity significantly and positively impacts the quantitative and qualitative forward-looking disclosure presented in integrated reports. Similarly, Vitolla et al. (2020a, 2020b) showed a positive relationship between the presence of female directors and IR quality.

Some studies (Amorelli \& García-Sánchez, 2020; Bear et al. 2010; Cook \& Glass, 2017; Kassinis et al. 2016) analyzed the role and impact of women on boards according to Critical Mass theory, which suggests that a critical mass of (at least three) women on the board can enhance corporate value creation (Carver, 2002; Cassell, 2000). This effect is related to the fact that when the size of a minority group increases (as in the case of women on the board), the majority can benefit from new resources, competences and perspectives (Kanter, 1977a, 1977b; Westphal \& Milton, 2000) and higher quality in decision making can be achieved (Amason, 1996; Hoffman \& Maier, 1961; Hoffman, 1959). Fernandez-Feijoo et al. (2014) proposed that the presence of at least three women on the board has a positive impact on CSR disclosure. Ben-Amar et al. (2017) found that the level of climate change disclosure increases with a certain percentage of women on the board. Manita et al. (2018) found a similar effect in studying the impact of the presence of women on the amount of ESG disclosure. Amorelli and Garcia-Sanchez (2020) found that an increase in the number of female directors to a critical mass has a positive impact on the quality of CSR disclosure, and that this influence is greater in the presence of better background, skills, and experience of board members.

However, other studies found a nonsignificant (Giannarakis et al. 2014; Khan, 2010; Prado-Lorenzo \& García-Sánchez, 2010) or negative association of female directors on the board with different types of disclosure (Lorenzo et al. 2009). Fasan and Mio (2017) found that the presence of women on the board worsens the materiality disclosure quality. They explain their findings stating that issues in the implementation of IR and in determining materiality push companies to "employ board diversity as a signal to markets that is not followed by actual actions" (Fasan \& Mio, 2017: 302). Muttakin et al. (2015) and Shamil et al. (2014) showed similar results regarding CSR disclosure. With reference to a 
sample of Italian companies, Cucari et al. (2018) found a negative relationship between women on the board and ESG disclosure. This finding is also consistent with that of Giannarakis $(2014 a, 2014 b)$ and may be a result of the low presence of women on Italian Boards.

The negative association between the presence of women on the board and disclosure can be explained by Token theory (Kanter, 1977b), which underlines how being a member of an under-represented group, as women on the board usually are, may cause difficulties in effectively contributing to board decisions (Nielsen \& Huse, 2010).

Board members' ethnicity and age represent other relevant diversity characteristics of a board considered by previous literature. Haniffa and Cooke (2005) studied the Malaysian case and report that the cultural identification of directors is associated with a firm's corporate social disclosure. In particular, they found that a higher number of native board members has a significant positive impact on the volume of the information disclosed. This relationship stems from the different perspectives, skills and knowledge as well as varied values, norms and understanding that result from diversity on the board (Ruigrok et al. 2007). Consequently, the presence of different culture on the board may enrich corporate decisions and foster a firm's disclosure (Ameer et al. 2010; Makkonen et al. 2018; Rao \& Tilt, 2016).

Differences in the age of board members have gained increasing attention in the CSR and sustainability literature. Some previous contributions highlighted that age difference positively influences CSR (Post et al. 2011). On the contrary, Hafsi and Turgut (2013) found that age difference has a negative significant impact on social performance. Bonn et al. (2004) showed that the age of directors is negatively associated with the firm performance of Japanese companies. Katmon et al. (2019) proposed that board age is negatively related to the quality of CSR disclosure. Finally, for some authors differences in the age of board members result in different level of expertise or maturity in managing the business. For instance, young directors pay more attention to ethical and environmental issues (Bekiroglu et al. 2011), while older directors concentrate their efforts on the creation of social welfare (de Villiers et al. 2017).

We also have to consider diversity in the education, professional background and previous experience of board members; in particular, their educational background contributes to define their knowledge and skills. Previous literature suggested that firms characterized by managers with a low level of education are exposed to high performance variability (Hambrick \& Mason, 1984). Some studies investigated the impact of executives' educational background (for example degree, MBA or doctoral degree) and suggested a positive influence on firm performance (Cheng \& Courtenay, 2006; Hambrick et al. 1996), while other studies found a positive relationship between the level of education of CEOs or directors and the amount of information disclosed (Raman \& Bukair, 2013; Yasser et al. 2017). In particular, Lewis et al. (2014) highlighted that CEOs with an MBA are more likely to disclose information on the company's environmental performance.

If we consider the literature on the relation between the board characteristics and disclosure and IR quality as a whole we can note that different authors used different reference theories to support the role and relevance of different board characteristics. 
In particular stakeholder theory supports the relevance of board size because larger boards are more likely to address a wide range of stakeholders. Agency theory explains the importance of the composition of the board, in terms of the presence of external nonexecutive members; boards with a higher proportion of independent directors are more effective in monitoring and controlling management, and thus in dealing with agency conflicts. Stakeholder theory also represents a theoretical reference framework concerning the impact of board diversity. In fact, diversity increases the board's ability to consider the various needs of different categories of stakeholders. However, if we look at diversity in terms of differences in the personal characteristics of the board members (gender, age and education), the studies on the quality of disclosure have also considered Upper echelons theory, Critical Mass theory, and Token theory. Upper echelons theory contributes to understanding how the personal characteristics of board members may influence the quality of the disclosure, whereas when we consider the role that a minority group can play within a larger group, two other theories become relevant: Critical Mass theory and Token theory. The first proposes that when the size of a minority group increases, the majority can benefit in terms of higher quality in decision making, while the second suggests that being a member of an under-represented group may make it difficult to effectively contribute to the group's decisions.

Figure 1 summarizes the relationship between different characteristics of the board and the main related theories.

\section{Research framework and design}

\subsection{Hypothesis}

This paper aims at enriching previous literature by identifying and testing some characteristics of the Board of Directors that can be considered determinants of IR quality. Previous literature suggested that the quality of disclosure and IR are

Theory

Board characteristics

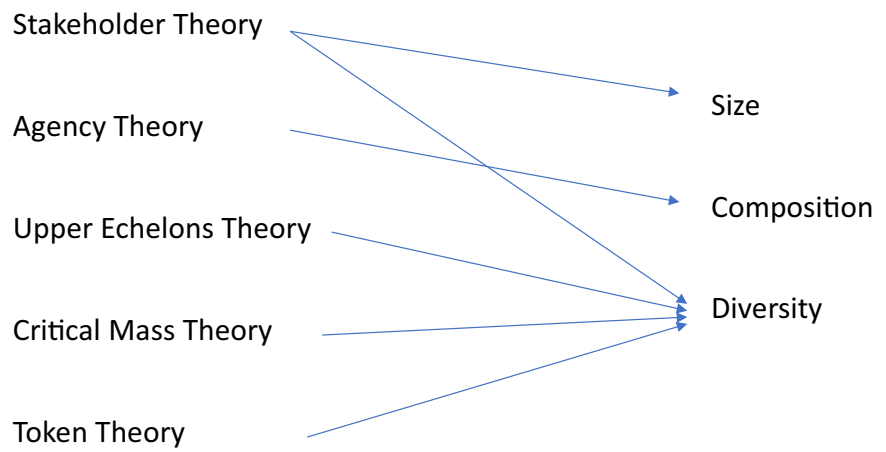

Fig. 1 Board characteristics and theories, as suggested by previous studies 
affected by the characteristics of the board and, specifically, by its size and composition (Busco et al. 2019; Michelon \& Parbonetti, 2012; Qu et al. 2015; Wang \& Hussainey, 2013).

According to stakeholder theory, larger boards safeguard the different stakeholder interests by stimulating wide and complete information disclosure (Amran et al. 2014; Frìas-Aceituno et al. 2012; Richardson \& Welker, 2001). In particular, the presence of a higher number of board members increases diversity in terms of expertise and experience. This aspect may impact the voluntary disclosure decisions of managers and, as a direct consequence, may increase the level of disclosure (Elzahar \& Hussainey, 2012; Wang \& Hussainey, 2013) and its quality (Qu et al. 2015). Moreover, some scholars suggested that with a larger board the effectiveness and efficiency of its functions increase and, as a consequence, there is an improvement in the level of companies' transparency, which also produces better disclosure (Gallego-Alvarez et al. 2011; Gandía, 2008; Hidalgo et al. 2011). This also leads to an improvement in the disclosure choices of companies (Adams et al. 2005). Moreover, in the specific field of IR, Vitolla et al. (2020a, 2020b) confirmed that the size of the board is positively correlated with the quality of integrated reports.

Consistently with these studies, we propose the following hypothesis:

HP1 The bigger the board size, the more the quality of IR improves.

The presence of a majority of independent directors improves the effectiveness of the board (Frías-Aceituno et al. 2012; Liao et al. 2015) and, by reducing agency costs and monitoring managers more efficiently, this may force management to disclose more information (Wang \& Hussainey, 2013), with an increase in both quality and quantity of voluntary disclosure (Fama \& Jensen, 1983). Vitolla et al. (2020a, 2020 b) suggested that there is a positive relationship between the number of nonexecutive directors and IR quality.

Therefore, we suggest the following hypothesis:

HP2 The higher the number of nonexecutive directors, the more the quality of IR improves.

Previous literature investigated the role of board gender diversity on voluntary disclosure (Alfiero et al. 2017; Frías-Aceituno et al. 2012) and on environmental disclosure quality (Rupley et al. 2012), finding that the presence of women has a positive impact on these types of disclosure and, in particular, that it increases a firm's disclosure on materiality (Rao \& Tilt, 2016).

These results are related to the fact that female directors are seen to be more participative (Eagly et al. 2003), democratic (Eagly \& Johnson, 1990) and communal than men (Rudman \& Glick, 2001). Moreover, women typically have a wide range of knowledge and skills and different perspectives (Harjoto et al. 2015; Hillman et al. 2002). Critical mass theory (Kanter, 1977a, 1977b, 1987; Granovetter, 1978) claims that when the size of a small subgroup increases, it can exercise greater influence. In the case of women, Kanter (1977a) suggested that they can produce an influence 
within an environment dominated by men only if they reach a consistent number. A critical mass effect was found also in studies on the impact of board gender diversity on disclosure (Ben-Amar et al. 2017; Manita et al. 2018). With reference to IR, Vitolla et al. (2020a, 2020b) showed that boards with a greater number of women positively impact the quality of the integrated reports.

Thus, we propose the following hypothesis:

HP3 The higher the number of female board members, the more the quality of IR improves.

Pistoni and Songini (2013) and Pistoni et al. (2016) identified internal and external determinants of CSR and CSR disclosure, proposing that the internal ones, such as company values and objectives, top management's values, commitment and personal features (gender, age, professional experience, etc.) have greater importance. A stream of literature has highlighted that cultural diversity of board members (due to different skills, knowledge and values) has a positive impact on financial and non-financial reporting (Haniffa \& Cooke, 2005; Harjoto et al. 2015; Ruigrok et al. 2007). In particular, some studies found a positive impact of executives' educational background (for example degree, MBA or doctoral degree) on firm performance (Cheng \& Courtenay, 2006; Hambrick et al. 1996), as well a positive relationship between the level of education of CEOs or directors and the amount of information disclosed (Raman \& Bukair, 2013; Yasser et al. 2017).

Accordingly, we propose the following hypothesis:

HP4 The higher the level of education of board members, the more the quality of IR improves.

Some authors highlighted that the age of board members positively influences corporate social responsibility (Post et al. 2011), while others found that age difference has a negative significant impact on social performance (Bonn et al. 2004; Hafsi \& Turgut, 2013). Katmon et al. (2019). Alfiero et al. (2017) found that board members' age is negatively associated with the quality of CSR disclosure and IR.

As a result, we introduce the following hypothesis:

HP5 The lower the average age of board members, the more the quality of IR improves.

\subsection{Variables}

\subsubsection{Dependent variable}

Previous literature proposed different methods to assess IR quality (Havlová, 2015; Lipunga, 2015; Pistoni et al. 2018; Stent \& Dowler, 2015) or some aspects of it (Fasan \& Mio, 2017; Frías-Aceituno et al. 2013; Gerwanski et al. 2019; Kiliç 
\& Kuzey, 2018; Melloni et al. 2016). Most authors applied a content analysis methodology.

As we focused on the quality of the whole integrated report, we referred to the Integrated Reporting Scoreboard (IRS) proposed by Pistoni et al. (2018) and in particular to its Content area. This area assesses the consistency of the IR document with the prescriptions of the IR framework regarding eight elements (organizational overview and external environment, business model, risks and opportunities, strategy and resource allocation, governance, performance, outlook, and basis of presentation) and two fundamental concepts (Capitals and Value creation process) (Pistoni et al. 2018). We focused on the Content area insofar as it considers the key distinctive features of IR that distinguish it from other types of voluntary disclosure (i.e. sustainability reporting). Actually, it considers all relevant elements and fundamental concepts of the IIRC framework. Moreover, the IRS uses a scoring system based on a scale of values between 0 and 5, and not simply a binary scoring system (Lipunga, 2015; Stent \& Dowler, 2015). Finally, it has been adopted to define and measure the IR quality by many other authors (Beretta et al. 2020; Raimo et al. 2020; Vitolla et al. 2019a, 2019b, 2020a, 2020b; Zhang et al. 2020).

Thus, in this study we chose the Content Area as the dependent variable (Dscore).

Following the scoring system proposed by Pistoni et al. (2018), we used a quantitative scale to assess the Content Area, considering the presentation of the topic, its description and the presence of explicit references to the IR guiding principles, where each variable has a score between 0 (absence) and 5 (very high quality). The maximum score achievable is 50 (or, in other words, the score of 5 per 10 items of the report considered: organizational overview and external environment, business model, risks and opportunities, strategy and resource allocation, governance, performance, outlook, basis of presentation, capitals and value creation process).

Table 1 shows details of the scoring system of the Content Area.

Data collection was carried out through the application of the manual content analysis technique (Weber, 1990) on the 212 integrated reports referring to the 53 companies. Consequently, we read all the integrated reports manually and did not use any software for collecting and analyzing data. Content analysis allows for codifying written text into groups or categories based on selected criteria (Krippendorff,

Table 1 Scoring system of the Content Area

\begin{tabular}{ll}
\hline Score & Description \\
\hline 0 & Content element absent \\
1 & Content element present, but poor description and scarce reference to the IR guiding principles \\
2 & Content element present; description based on some quantitative information and on a few IR \\
& guiding principles \\
3 & $\begin{array}{c}\text { Content element present; balanced description of contents; average quantity of information that } \\
\text { refers to IR guiding principles }\end{array}$ \\
4 & Content element present; good and detailed description of contents; many IR guiding principles \\
& considered
\end{tabular}


1980). In order to avoid subjectivity problems and to ensure consistency of the scoring results, two researchers read and assessed each report. On reading the entire company report, they autonomously attributed the score to the Content Area and, more in detail, to the description of the eight elements of the IR framework and of the two fundamental concepts. They were trained in the scoring protocol to ensure the reliability of the analysis (Krippendorff, 1980). An inter-rater reliability check (intra-class correlation calculation) was then performed with satisfactory results.

The content disclosure score of each year for each company was obtained from the sum of the scores obtained in the ten items analyzed within the report. Finally, the content disclosure score index of a company was obtained by the average content scores given by the two researchers for each of the four years $(2013,2014,2015$, 2016) considered.

Table 2 presents the content disclosure score index for the four years.

\subsubsection{Independent variables}

Independent variables concern board characteristics. We collected data on board size, composition (number of independent and nonexecutive members) and diversity (gender, birth year, education level of the board members) from integrated reports and companies' websites. Independent variables were defined and measured as follows.

3.2.2.1 Board size (TotalNum) Board size is measured as the total number of board members, consistently with many previous studies (Busco et al. 2019; Fasan \& Mio, 2017; Frías-Aceituno et al. 2012; Melloni et al. 2016).

3.2.2.2 Board composition (NonExec) This is measured as the total number of independent members of the board (Allini et al. 2016).

3.2.2.3 Board diversity-gender We used the number of women on the board as a proxy of board diversity (Female) (Allini et al. 2016). To check for robustness, we used the percentage of women on the board (Femaleperc) as an alternative proxy (Fasan \& Mio, 2017; Kiliç \& Kuzey, 2018).

3.2.2.4 Board diversity-age For some authors differences in the age of board members correspond to different levels of expertise or maturity in managing the business. For instance, Bekiroglu et al. (2011) suggested that young directors pay

Table 2 Content Disclosure score index for the four years

\begin{tabular}{lllllll}
\hline Year & Variable & Obs & Mean & Std. Dev & Min & Max \\
\hline 2013 & Content Dscore & 53 & 25.62264 & 5.447217 & 16 & 38.5 \\
2014 & Content Dscore & 53 & 29.08491 & 5.246552 & 12 & 39.5 \\
2015 & Content Dscore & 53 & 27.5566 & 6.666983 & 11 & 41.5 \\
2016 & Content Dscore & 53 & 33.20755 & 5.951272 & 10 & 43.5 \\
\hline
\end{tabular}


more attention to ethical and environmental issues, while de Villiers et al. (2017) suggested that older directors concentrate their efforts on the creation of social welfare. Thus, in order to distinguish the effect of having young and/or old members on the board, we used a dummy variable (Yage) that takes on the value of 1 if the average age of board members is lower than the average age of the sample (57.2 years) and 0 otherwise.

To check for robustness, we used a continuous variable representing the average age of board members (Avage) as an alternative to Yage (Bonn et al. 2004).

3.2.2.5 Board diversity-educational level As far as the education level is concerned, we split the members of the board into two categories based on the achievement of 1) a degree or an MBA, and 2) a PhD. We collected respectively the number of board members with a post graduate degree or an MBA (Postgrad) and with a PhD (PhD).

\subsubsection{Control variables}

Typical control variables used in previous studies have been identified and used in this paper. They are described below.

3.2.3.1 Industry type We used a dummy variable (Industry) assuming the value of 0 for manufacturing and other industrial activities and 1 otherwise.

3.2.3.2 Region We used a dummy variable (Region) assuming the value of 0 for Anglo Saxon countries and 1 otherwise.

3.2.3.3 Firm size Consistently with previous contributions (Boesso \& Kumar, 2007; Songini et al. 2020), we referred to the number of employees for each year of the period analyzed. In order to solve potential issues related to heteroscedasticity and outliers, we decided to log transform the average number of employees and we used the natural logarithm as a control variable (LnNempl). We checked the effect of the natural logarithm of total assets as an alternative control variable for size.

3.2.3.4 Leverage The variable leverage (Lev) was obtained from the net financial debt scaled by equity for each of the four years considered, as suggested by previous studies (Muttakin \& Khan, 2014).

3.2.3.5 Profitability As an indicator of profitability (ROE), we used the 2013, 2014, 2015 and 2016 return on equity - ROE (Wang et al. 2008).

3.2.3.6 Ownership We used a dummy variable (Ownership) assuming the value of 0 for Publicly listed and 1 otherwise.

Table 3 summarizes the definition and measurement of all the variables. 


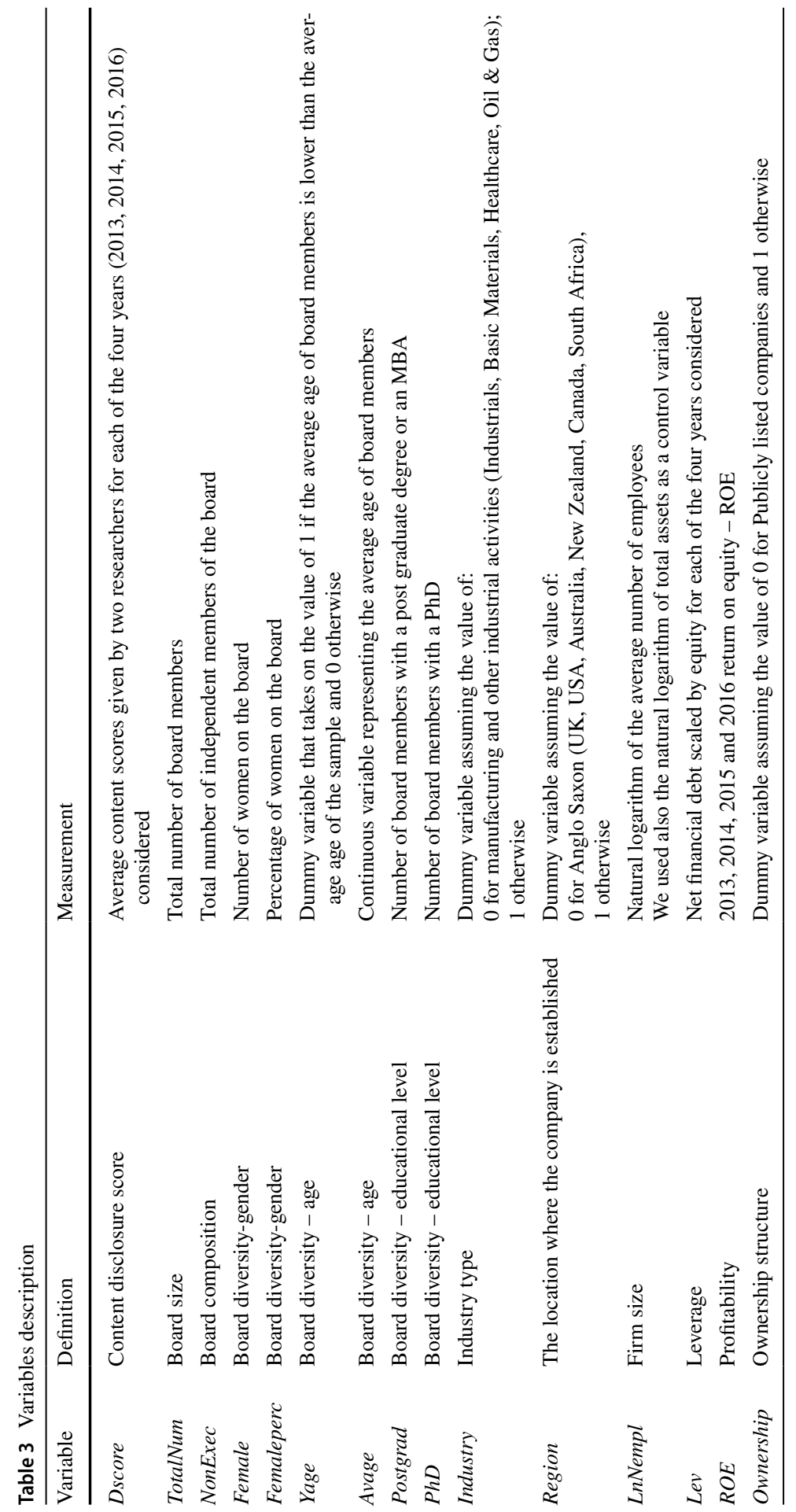




\subsection{Sample and data collection}

We examined 276 integrated reports downloaded between December 2016 and October 2018 from the 'Getting Started' section of the IR examples website (http://examples.integratedreporting.org/home) filtered for the years 2013 (63 reports available), 2014 (65 reports), 2015 (94 reports) and 2016 (54 reports). Then, in order to make a significant comparison, we selected only the reports of firms which published the IR for all four years, excluding 60 reports ( 7 firms only published their report in 2014, 5 only in 2013, 3 firms only in 2013 and 2014, 39 only in 2015 and 1 only in 2013, 2014 and 2015). We removed one company (and its four integrated reports) from the sample, as not all the data were available in the period analyzed. Thus, our final sample consisted of 212 reports (53 reports for each year analyzed).

Consistently with Pistoni et al. (2018), we assumed that the reports published in the "Getting Started" section can be considered as best practice, as they are suggested by the IIRC as a reference point in the application of the IR framework. Since our study was conducted from 2016 to 2018, we decided to consider four years $(2013,2014,2015$ and 2016). We selected 2013 as the starting point of the analysis because that is the year the IIRC published the "Consultation draft on the International $<$ IR $>$ framework", and then the "International $<$ IR $>$ framework". This means that reports published after 2013 should be consistent with the guidelines provided by the IIRC (Pistoni et al. 2018).

Table 4 shows the main features of the 53 companies analyzed.

Out of the 53 firms included in the sample, 24 are manufacturers or perform industrial activities, 13 provide financial services and 16 other services. Figure 2 shows the detail of the industry distribution.

30 firms are located in Anglo Saxon countries, 9 in Europe and 14 in other countries; 9 firms are established in countries where IR is mandatory (South Africa). The majority of the firms included in the sample are Publicly listed companies $(88.68 \%$ ), while a few come from the Public Sector $(9.43 \%)$ or are Private companies (1.89\%). Finally, considering the number of employees of each firm, the sample refers to large enterprises.

\subsection{Methodology}

Given the perfectly balanced panel structure of the data set we decided to run a panel analysis. To choose between fixed effect (FE) and random effect (RE), we took the characteristics of our data into account. As we know, the FE model explores the relationship between independent and dependent variables within an entity (in our case the single companies) assuming that each entity has its own individual characteristics, which may or may not be related to the predictor variables (for instance board gender composition), removing the effect of time-invariant characteristics, while the RE model can also test the effect of those individual time invariant characteristics that are wiped out in the fixed effect model. 
Table 4 Sample description

\begin{tabular}{|c|c|c|}
\hline \multicolumn{3}{|l|}{ Sample description } \\
\hline \multicolumn{3}{|l|}{ Sample size } \\
\hline \multicolumn{2}{|l|}{ Number of reports } & 276 \\
\hline \multicolumn{3}{|l|}{ Less: } \\
\hline \multicolumn{2}{|l|}{$\begin{array}{l}\text { reports not available for all the years or } \\
\text { incomplete information }\end{array}$} & 64 \\
\hline \multicolumn{2}{|l|}{ Total } & 212 \\
\hline \multicolumn{3}{|l|}{ Industry distribution } \\
\hline Industry sector & No. of firms & Percent \\
\hline Manufacturing/Industrials & 24 & $45.28 \%$ \\
\hline Financial services & 13 & $24.53 \%$ \\
\hline Other services & 16 & $30.19 \%$ \\
\hline Total & 53 & $100 \%$ \\
\hline \multicolumn{3}{|l|}{ Country system } \\
\hline Category & No. of firms & Percent \\
\hline Anglo Saxon & 30 & $56.60 \%$ \\
\hline Europe & 9 & $16.98 \%$ \\
\hline Other & 14 & $26.42 \%$ \\
\hline Total & 53 & $100 \%$ \\
\hline \multicolumn{3}{|l|}{ Mandatory adoption of IR } \\
\hline $\begin{array}{l}\text { Firms operating in countries where IR is } \\
\text { mandatory }\end{array}$ & 9 & $16.98 \%$ \\
\hline Other & 44 & $83.02 \%$ \\
\hline Total & 53 & $100 \%$ \\
\hline \multicolumn{3}{|l|}{ Organization type } \\
\hline Publicly listed companies & 47 & $88.68 \%$ \\
\hline Public sector & 5 & $9.43 \%$ \\
\hline Private companies & 1 & $1.89 \%$ \\
\hline Total & 53 & $100 \%$ \\
\hline \multicolumn{3}{|l|}{ Organization size (no. of employees) } \\
\hline Up to 10,000 & 21 & $39.62 \%$ \\
\hline $10,001-50,000$ & 17 & $32.08 \%$ \\
\hline $50,001-100,000$ & 11 & $20.75 \%$ \\
\hline More than 100,000 & 4 & $7.55 \%$ \\
\hline Total & 53 & $100 \%$ \\
\hline
\end{tabular}

The presence in our dataset of some important variables to be checked and whose values did not change across time (i.e. Ownership, Region, Industry) was the first reason to prefer RE.

The second reason was that the differences across entities could influence the Dscore.

From an operational point of view, as in Fasan and Mio (2017), we followed the results of the Hausman test, which in our case confirmed the choice of Random Effect. The Breusch-Pagan LM test for random effects rejected the 


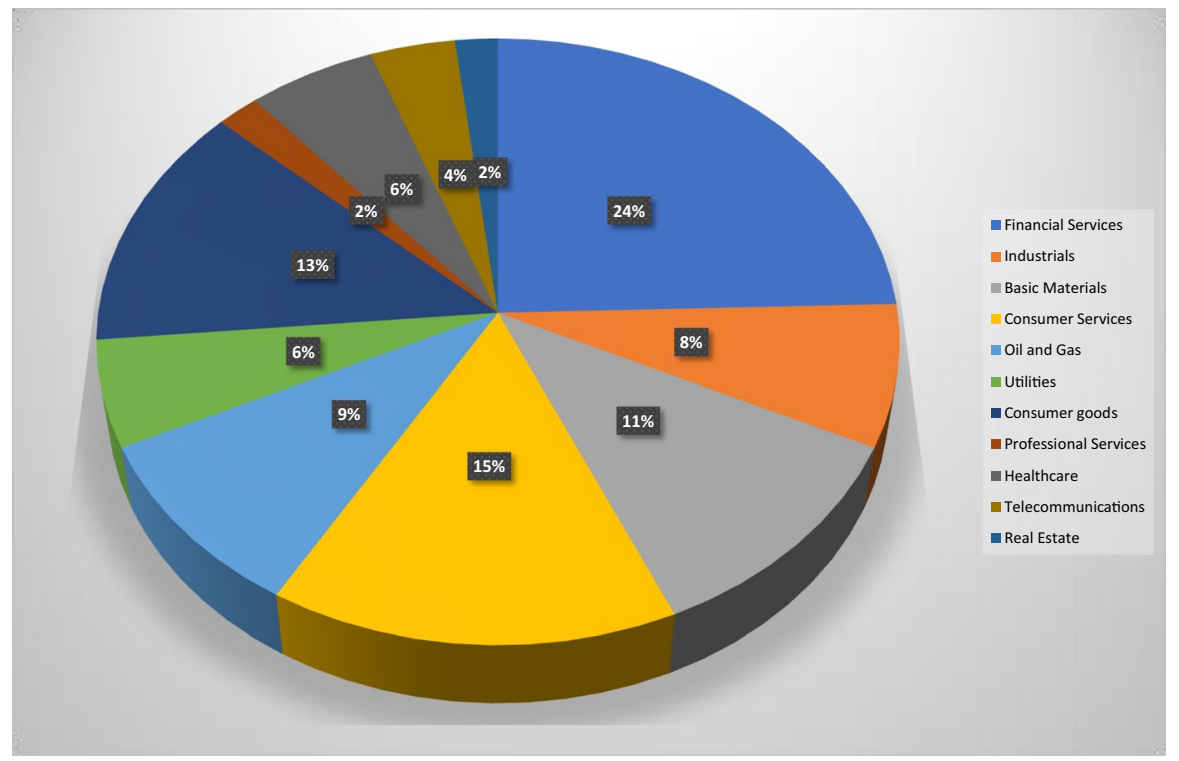

Fig. 2 Industry distribution

hypotheses of zero variance across entities and allowed us to confirm the use of a RE regression instead of a simple OLS regression.

The RE model is the following:

Model 1. Dscore ${ }_{i t}=\alpha+\beta_{1}$ TotalNum $_{i t}+\beta_{2}$ NonExec $_{i t}+\beta_{3}$ Gender $_{i t}+\beta_{4}$ Age $_{i t+}$ $\beta_{5}$ Postgrad $_{i t}+\beta_{6}$ Phd $_{i t+} \beta_{7}$ LnNempl $_{i t}+\beta_{8}$ Lev $_{i t}+\beta_{9}$ ROE $_{i t}+\beta_{10}$ Ownership $_{i+}$ $\beta_{11}$ Region $_{i}+\beta_{12}$ Industry $_{i+} \beta_{13}$ Year2014 $_{+} \beta_{14}$ Year2015 $_{+} \beta_{15}$ Year2016 $+\mathrm{u}_{i t}$.

According to previous literature (Adams et al. 2010; Hermalin \& Weisbach, 1998) board structure is more likely to be endogenous insofar as economic players can choose board structures to solve governance problems and this may particularly be the case with board gender diversity. Both reverse causality and differences in unobservable characteristics can bias the results of the analysis in a significant way.

Some relevant papers (Bellemare et al. 2017; Boulouta, 2013; Busco et al. 2019; Manita et al. 2018) suggest the use of lagged firm specific characteristics to address endogeneity. Accordingly, we tested the following model with all firm specific variables lagged by 1 year:

Model 2. Dscore ${ }_{i t}=\alpha{ }_{+} \beta_{1}$ TotalNum $_{i t-1}+\beta_{2}$ NonExec $_{i t-1+} \beta_{3}$ Gender $_{i t-1}{ }_{+} \beta_{4}$ Age $_{i t-1+}$ $\beta_{5} \operatorname{Postgrad}_{i t-1+} \beta_{6} \quad \operatorname{Phd}_{i t-1+} \beta_{7} \operatorname{LnNempl}_{i t-1+} \beta_{8} \quad \operatorname{Lev}_{i t-1+} \beta_{9} \mathrm{ROE}_{i t-1}+\beta_{10} \quad$ Ownership $_{i+} \beta_{11}$ Region $_{i}+\beta_{12}$ Industry $_{i+} \beta_{13}$ Year2014 ${ }_{+} \beta_{14}$ Year2015 $+\beta_{15}$ Year2016 $+\mathrm{u}_{i r}$

The results of the multivariate analysis are reported in Section 3.3. 


\section{Research findings}

\subsection{Descriptive statistics}

Table 2 presents the content disclosure score index (Dscore) for four years (2013, 2014, 2015, 2016). During the period considered we can see that the maximum value and the average level increase, while the minimum value decreases. The global effect results in a weak increase in the average quality of the content disclosure score index in the period 2013-2016. The standard deviation of this value always remains quite low.

Table 5 presents data on board description and composition for the four years analyzed. With reference to the board description, we can observe the average board size (11.8) and the average age of board members (57.2), which is quite high. The age of the majority of the members is over 50 (77.44\%). Regarding the board composition, the average percentage of independent members out of the total board members is $50.37 \%$ and there is a clear predominance of male members $(78.47 \%$ against the $21.53 \%$ of female members).

Table 6 focuses on board members' education level for the years 2013-2016. The education level is quite high: the majority of the members have a degree (72.48\%), $15.40 \%$ hold an MBA, but only a small percentage $(12.44 \%)$ have a PhD.

Table 7 shows gender diversity in the board. Female members are generally younger than male members: their average age is 54.7 against the 58.22 of male members. Moreover, the number of nonexecutive members is higher among women (79.28\%) than among men $(63.29 \%)$, even though, due to an overall higher presence of male members on the board, we observe also a higher number of male nonexecutives $(71 \%)$. Concerning the education level of board members, a high percentage of men $(68.09 \%)$ and women $(86.25 \%$ ) have a degree, but the number of $\mathrm{PhDs}$ and MBAs is higher among male members (respectively $13.75 \%$ and $18.26 \%$ ).

Table 5 Board description and composition

\begin{tabular}{ll}
\hline Board description and composition & \\
\hline Board description & \\
Average Board size & 11.8 \\
Average age of Board members: & 57.2 \\
50 or under & $22.56 \%$ \\
Over 50 & $77.44 \%$ \\
Total & $100 \%$ \\
Board composition & \\
Average Independents/tot Board & $50.37 \%$ \\
Gender: & \\
$\%$ male & $78.47 \%$ \\
$\%$ female & $21.53 \%$ \\
Total & $100 \%$ \\
\hline
\end{tabular}


Table 6 Board members' education level

Table 7 Board gender diversity

Board gender diversity

\begin{tabular}{ll}
\hline Board gender diversity & \\
\hline Age $^{\circ} \mathrm{C}$ & \\
Average age of male Board members: & 58.22 \\
50 or under & $18.64 \%$ \\
Over 50 & $81.36 \%$ \\
Total & $100 \%$ \\
Average age of female Board members: & 54.7 \\
50 or under & $28.60 \%$ \\
Over 50 & $71.40 \%$ \\
Total & $100 \%$ \\
Nonexecutive members & \\
Male nonexecutive members/Tot nonexecutives & $71 \%$ \\
Female nonexecutive members/Tot nonexecutives & $29 \%$ \\
Total & $100 \%$ \\
Male nonexecutive members/Tot male & $63.29 \%$ \\
Female nonexecutive members/Tot female & $79.28 \%$ \\
Male Board members' education level & \\
Degree & $68.09 \%$ \\
Phd & $13.75 \%$ \\
MBA & $18.26 \%$ \\
Total & $100 \%$ \\
Female Board members' education level & \\
Degree & $86.25 \%$ \\
Phd & $6.17 \%$ \\
MBA & $7.46 \%$ \\
Total & $100 \%$ \\
\hline
\end{tabular}

Board members' education level

\begin{tabular}{ll}
\hline Board members' education level & \\
Degree & $72.48 \%$ \\
Phd & $12.44 \%$ \\
MBA & $15.40 \%$ \\
Total & $100 \%$ \\
\hline
\end{tabular}

It is noteworthy that, in our sample, women on boards are mostly graduates in social sciences and humanities, while men mostly have a degree, MBA or PhD in engineering, economics and other scientific fields. More than $30 \%$ of women can be found in listed firms operating in Europe, and in particular in the UK, and in financial services and other services.

Table 8 provides the descriptive statistics for the variables used in this work. 
Table 8 Descriptive Statistics

\begin{tabular}{lcclll}
\hline Variable & Obs & Mean & Std. Dev & Min & Max \\
\hline Dscore & 212 & 28.86792 & 6.449697 & 10 & 43.5 \\
TotalNum & 212 & 11.76887 & 3.239035 & 5 & 22 \\
NonExec & 212 & 8.004717 & 3.539215 & 0 & 19 \\
Female & 212 & 2.570755 & 1.6721 & 0 & 7 \\
Average & 212 & 57.40522 & 3.849118 & 46.4 & 67.11 \\
Master & 212 & 1.801887 & 1.602248 & 0 & 8 \\
PHD & 212 & 1.466981 & 1.923623 & 0 & 15 \\
LnNempl & 212 & 9.593465 & 1.75754 & 4.80 & 12.59 \\
Lev & 212 & 1.172059 & 2.683417 & -4.02 & 17.86 \\
ROE & 212 & 0.1375596 & 0.4014278 & -0.52 & 5.16 \\
\hline
\end{tabular}

The average disclosure content score is 28.9 out of 50 . Thus, on average the sample companies do not show a remarkable performance in terms of the quality of integrated reports.

The average number of members on the board is 11.8 , while, regarding the composition of the board, the average presence of nonexecutive directors is around 8 and the average number of female directors is around 3. The average natural logarithm for the number of employees is 9.59 .

The average leverage is around 1.17 . The average ROE for the sample is $13.7 \%$.

\subsection{Univariate analysis}

The correlation among the independent variables is not high. This is confirmed by the multicollinearity diagnostics, in particular the VIF in the multivariate simple OLS regression analysis run on the whole data set varies from 1.22 to 2.59 with a mean value of 1.58. In a year by year examination the value is never higher than 4 . As in previous literature (Alfiero et al. 2018; Dilling \& Caykoylu, 2019; Michelon $\&$ Parbonetti, 2012) these values suggest that the model does not suffer from any multicollinearity problems.

\subsection{Multivariate analysis}

Table 9 reports the results of the random effect model with robust standard errors for Model 1 and random effect with lagged firm specific variables for Model 2.

To check for robustness, we alternatively used variables Female and Femaleperc for gender and variables Avage and Yage for age. The results are shown in Table 9

As a robustness analysis, we ran the models dropping out 6 observations per year referred to companies located in South Africa, where IR is mandatory. The results are shown in Table 10.

With reference to the hypotheses formulated before, we observe the following results. 
Table 9 Results for Model 1 and Model 2 (whole sample)

\begin{tabular}{|c|c|c|c|c|c|c|c|c|}
\hline & \multicolumn{4}{|c|}{ Random Effect } & \multicolumn{4}{|c|}{ Lagged Random Effect } \\
\hline & A & B & $\mathrm{C}$ & $\mathrm{D}$ & $\mathrm{E}$ & $\mathrm{F}$ & G & $\mathrm{H}$ \\
\hline & Dscore & Dscore & Dscore & Dscore & Dscore & Dscore & Dscore & Dscore \\
\hline TotalNum & $\begin{array}{l}-0.0270 \\
(-0.12)\end{array}$ & $\begin{array}{l}-0.0183 \\
(-0.08)\end{array}$ & $\begin{array}{l}-0.154 \\
(-0.72)\end{array}$ & $\begin{array}{l}-0.153 \\
(-0.68)\end{array}$ & $\begin{array}{l}0.202 \\
(0.86)\end{array}$ & $\begin{array}{l}0.182 \\
(0.75)\end{array}$ & $\begin{array}{l}0.0109 \\
(0.06)\end{array}$ & $\begin{array}{l}0.0151 \\
(0.08)\end{array}$ \\
\hline NonExec & $\begin{array}{l}0.257 \\
(1.29)\end{array}$ & $\begin{array}{l}0.257 \\
(1.22)\end{array}$ & $\begin{array}{l}0.246 \\
(1.24)\end{array}$ & $\begin{array}{l}0.246 \\
(1.17)\end{array}$ & $\begin{array}{l}0.248 \\
(1.25)\end{array}$ & $\begin{array}{l}0.243 \\
(1.18)\end{array}$ & $\begin{array}{l}0.255 \\
(1.30)\end{array}$ & $\begin{array}{l}0.249 \\
(1.22)\end{array}$ \\
\hline Female & $\begin{array}{l}-0.611^{*} \\
(-1.75)\end{array}$ & $\begin{array}{l}-0.638^{*} \\
(-1.80)\end{array}$ & & & $\begin{array}{l}-0.901 * \\
(-1.77)\end{array}$ & $\begin{array}{l}-0.781 \\
(-1.53)\end{array}$ & & \\
\hline $\begin{array}{l}\text { Female- } \\
\text { perc }\end{array}$ & & & $\begin{array}{l}-4.473 \\
(-1.15)\end{array}$ & $\begin{array}{l}-4.509 \\
(-1.15)\end{array}$ & & & $\begin{array}{l}-11.22 * * \\
(-2.14)\end{array}$ & $\begin{array}{l}-9.675^{*} \\
(-1.82)\end{array}$ \\
\hline Avage & $\begin{array}{l}-0.146 \\
(-1.04)\end{array}$ & & $\begin{array}{l}-0.136 \\
(-0.98)\end{array}$ & & $\begin{array}{l}-0.254^{*} \\
(-1.70)\end{array}$ & & $\begin{array}{l}-0.268^{*} \\
(-1.75)\end{array}$ & \\
\hline Yage & & $\begin{array}{l}1.702 * * \\
(2.04)\end{array}$ & & $\begin{array}{l}1.609 * * \\
(1.99)\end{array}$ & & $\begin{array}{l}0.691 \\
(0.68)\end{array}$ & & $\begin{array}{l}0.722 \\
(0.69)\end{array}$ \\
\hline Postgrad & $\begin{array}{l}0.688 * * \\
(2.56)\end{array}$ & $\begin{array}{l}0.696^{* *} \\
(2.54)\end{array}$ & $\begin{array}{l}0.675^{* *} \\
(2.52)\end{array}$ & $\begin{array}{l}0.681^{* *} \\
(2.49)\end{array}$ & $\begin{array}{l}0.897 * * \\
(2.24)\end{array}$ & $\begin{array}{l}0.801 * \\
(1.91)\end{array}$ & $\begin{array}{l}0.894 * * \\
(2.27)\end{array}$ & $\begin{array}{l}0.793 * \\
(1.91)\end{array}$ \\
\hline $\mathrm{PhD}$ & $\begin{array}{l}0.407 * * \\
(2.25)\end{array}$ & $\begin{array}{l}0.377 * * \\
(2.07)\end{array}$ & $\begin{array}{l}0.369 * * \\
(2.00)\end{array}$ & $\begin{array}{l}0.339 * \\
(1.82)\end{array}$ & $\begin{array}{l}0.285 \\
(0.88)\end{array}$ & $\begin{array}{l}0.202 \\
(0.70)\end{array}$ & $\begin{array}{l}0.265 \\
(0.83)\end{array}$ & $\begin{array}{l}0.181 \\
(0.64)\end{array}$ \\
\hline LnNempl & $\begin{array}{l}-0.391 \\
(-1.31)\end{array}$ & $\begin{array}{l}-0.366 \\
(-1.20)\end{array}$ & $\begin{array}{l}-0.372 \\
(-1.23)\end{array}$ & $\begin{array}{l}-0.344 \\
(-1.11)\end{array}$ & $\begin{array}{l}-0.418 \\
(-1.30)\end{array}$ & $\begin{array}{l}-0.392 \\
(-1.18)\end{array}$ & $\begin{array}{l}-0.424 \\
(-1.32)\end{array}$ & $\begin{array}{l}-0.396 \\
(-1.20)\end{array}$ \\
\hline Lev & $\begin{array}{l}-0.867 * * * \\
(-4.85)\end{array}$ & $\begin{array}{l}-0.849 * * * \\
(-4.58)\end{array}$ & $\begin{array}{l}-0.842 * * * \\
(-4.64)\end{array}$ & $\begin{array}{l}-0.825^{* * *} \\
(-4.37)\end{array}$ & $\begin{array}{l}-0.554 * * * \\
(-3.10)\end{array}$ & $\begin{array}{l}-0.585 * * * \\
(-3.18)\end{array}$ & $\begin{array}{l}-0.536^{* * * *} \\
(-2.94)\end{array}$ & $\begin{array}{l}-0.572^{* * * *} \\
(-3.07)\end{array}$ \\
\hline ROE & $\begin{array}{l}3.520 * * * \\
(4.25)\end{array}$ & $\begin{array}{l}3.347 * * * \\
(4.07)\end{array}$ & $\begin{array}{l}3.418 * * * \\
(4.03)\end{array}$ & $\begin{array}{l}3.266^{* * * *} \\
(3.88)\end{array}$ & $\begin{array}{l}-0.558 \\
(-0.26)\end{array}$ & $\begin{array}{l}-1.045 \\
(-0.43)\end{array}$ & $\begin{array}{l}-0.589 \\
(-0.28)\end{array}$ & $\begin{array}{l}-1.089 \\
(-0.46)\end{array}$ \\
\hline $\begin{array}{c}\text { Owner- } \\
\text { ship }\end{array}$ & $\begin{array}{l}-1.514 \\
(-0.93)\end{array}$ & $\begin{array}{l}-1.416 \\
(-0.86)\end{array}$ & $\begin{array}{l}-1.553 \\
(-0.95)\end{array}$ & $\begin{array}{l}-1.464 \\
(-0.89)\end{array}$ & $\begin{array}{l}-2.478 \\
(-1.35)\end{array}$ & $\begin{array}{l}-2.124 \\
(-1.05)\end{array}$ & $\begin{array}{l}-2.548 \\
(-1.41)\end{array}$ & $\begin{array}{l}-2.166 \\
(-1.07)\end{array}$ \\
\hline Region & $\begin{array}{l}1.458 \\
(1.31)\end{array}$ & $\begin{array}{l}1.517 \\
(1.31)\end{array}$ & $\begin{array}{l}1.684 \\
(1.49)\end{array}$ & $\begin{array}{l}1.766 \\
(1.50)\end{array}$ & $\begin{array}{l}1.968 \\
(1.56)\end{array}$ & $\begin{array}{l}1.869 \\
(1.43)\end{array}$ & $\begin{array}{l}1.906 \\
(1.56)\end{array}$ & $\begin{array}{l}1.807 \\
(1.43)\end{array}$ \\
\hline Industry & $\begin{array}{l}0.354 \\
(0.32)\end{array}$ & $\begin{array}{l}0.295 \\
(0.26)\end{array}$ & $\begin{array}{l}0.252 \\
(0.22)\end{array}$ & $\begin{array}{l}0.190 \\
(0.17)\end{array}$ & $\begin{array}{l}0.976 \\
(0.85)\end{array}$ & $\begin{array}{l}0.936 \\
(0.80)\end{array}$ & $\begin{array}{l}1.064 \\
(0.94)\end{array}$ & $\begin{array}{l}1.012 \\
(0.88)\end{array}$ \\
\hline $\begin{array}{l}\text { Year } \\
\text { effect }\end{array}$ & Yes & Yes & Yes & Yes & Yes & Yes & Yes & Yes \\
\hline Intercept & $\begin{array}{l}35.37 * * * \\
(4.35)\end{array}$ & $\begin{array}{l}25.99 * * * \\
(8.43)\end{array}$ & $\begin{array}{l}35.68 * * * \\
(4.34)\end{array}$ & $\begin{array}{l}26.96 * * * \\
(8.17)\end{array}$ & $\begin{array}{l}42.83 * * * \\
(5.28)\end{array}$ & $\begin{array}{l}28.16^{* * * *} \\
(8.41)\end{array}$ & $\begin{array}{l}46.02 * * * \\
(5.57)\end{array}$ & $\begin{array}{l}30.21 * * * \\
(8.48)\end{array}$ \\
\hline $\mathrm{Nr}$ of obs & 212 & 212 & 212 & 212 & 159 & 159 & 159 & 159 \\
\hline $\begin{array}{l}\mathrm{Nr} \text { of } \\
\text { groups }\end{array}$ & 53 & 53 & 53 & 53 & 53 & 53 & 53 & 53 \\
\hline Wald $X^{2}$ & 319.25 & 313.95 & 310.99 & 306.40 & 334.46 & 280.51 & 350.59 & 278.38 \\
\hline Prob $>X^{2}$ & 0.0000 & 0.0000 & 0.0000 & 0.0000 & 0.0000 & 0.0000 & 0.0000 & 0.0000 \\
\hline $\mathrm{R}^{2}$ overall & 0.3885 & 0.3874 & 0.3841 & 0.3828 & 0.3647 & 0.3419 & 0.3755 & 0.3503 \\
\hline
\end{tabular}


Table 9 (continued)

This table presents the results of a Random Effect Panel Regression (model 1) with no endogeneity corrections (columns A to D), of a Random Effect Panel Regression(Model 2) with lagged firm-specific variables as a treatment for endogeneity (columns $\mathrm{E}$ to $\mathrm{H}$ ) Heteroskedasticity consistent (robust) standard errors are used to compute $\mathrm{z}$ statistics. *,**, and *** denote significance at the 10,5 , and $1 \%$ levels, respectively

HP1 The bigger the board size, the more the quality of IR improves.

Looking at Table 9 we can find a positive (from 0.0109 to 0.202 ) but not significant coefficient (columns $\mathrm{E}$ to $\mathrm{H}$ ). These results are confirmed by the equations in Table 10. Thus, HP1 is not supported.

HP2 The higher the number of nonexecutive directors, the more the quality of IR improves.

The coefficient referred to the number of nonexecutive directors in Table 9 is positive (from 0.243 to 0.255 ) and not significant (columns $\mathrm{E}$ to $\mathrm{H}$ ). These results are confirmed by the equations in Table 10 . Thus, HP2 is not supported.

HP3 The higher the number of female Board members is, the more the quality of IR improves.

We observe a negative and significant coefficient in 3 out of 4 of the equations in Model 2 (Table 9).

In particular, we find one significant (at 10\%) and negative $(-0.901)$ relationship for the number of women (column E) and two significant (at 5\% and $10 \%$ respectively) and negative (respectively -11.22 and -9.675 ) relationships for the percentage of women on the board (columns $\mathrm{G}$ and $\mathrm{H}$ ).

Looking at the results of the equations in Table 10 (Model 2) we see that all the four equations (columns $\mathrm{E}$ to $\mathrm{H}$ ) show a significant $(5 \%)$ and negative (respectively $-0.955,-0.895,-11.43,-10.51)$ relationship. These results seem to be robust considering the use of different gender related variables (Female in columns $\mathrm{E}$ and $\mathrm{F}$ versus Femaleperc in columns $\mathrm{G}$ and $\mathrm{H}$ ).

Based on these results we can reasonably say that HP3 is not supported, as our findings show that when the number of women on the board is higher, the quality of IR is lower.

Although it was not our main purpose, in order to go deeper into these research findings and following some previous studies (Ben-Amar et al. 2017; Manita et al. 2018), we also checked the impact of a critical mass of women on the quality of IR in our regression. We obtained a negative but not significant effect in both model 1 and model 2. However, a partially different result occurred when testing the critical mass effect of at least 3 women in the sample, excluding those countries where IR is compulsory. In this case we obtained a not significant negative effect in Model 1, but a significant (at 10\%) negative effect in Model 2 (from -2.287 to -2.326). 
Table 10 Results for Model 1 and Model 2 (sample without companies located in South Africa)

\begin{tabular}{|c|c|c|c|c|c|c|c|c|}
\hline & \multicolumn{4}{|c|}{ Random Effect } & \multicolumn{4}{|c|}{ Lagged Random Effect } \\
\hline & A & B & $\mathrm{C}$ & $\mathrm{D}$ & $\mathrm{E}$ & $\mathrm{F}$ & G & $\mathrm{H}$ \\
\hline & Dscore & Dscore & Dscore & Dscore & Dscore & Dscore & Dscore & Dscore \\
\hline TotalNum & $\begin{array}{l}0.0149 \\
(0.07)\end{array}$ & $\begin{array}{l}0.0396 \\
(0.17)\end{array}$ & $\begin{array}{l}-0.0778 \\
(-0.37)\end{array}$ & $\begin{array}{l}-0.0630 \\
(-0.29)\end{array}$ & $\begin{array}{l}0.232 \\
(1.11)\end{array}$ & $\begin{array}{l}0.222 \\
(1.05)\end{array}$ & $\begin{array}{l}0.0402 \\
(0.24)\end{array}$ & $\begin{array}{l}0.0419 \\
(0.24)\end{array}$ \\
\hline NonExec & $\begin{array}{l}0.191 \\
(0.89)\end{array}$ & $\begin{array}{l}0.187 \\
(0.84)\end{array}$ & $\begin{array}{l}0.179 \\
(0.83)\end{array}$ & $\begin{array}{l}0.175 \\
(0.78)\end{array}$ & $\begin{array}{l}0.107 \\
(0.58)\end{array}$ & $\begin{array}{l}0.0968 \\
(0.52)\end{array}$ & $\begin{array}{l}0.114 \\
(0.63)\end{array}$ & $\begin{array}{l}0.101 \\
(0.55)\end{array}$ \\
\hline Female & $\begin{array}{l}-0.467 \\
(-1.29)\end{array}$ & $\begin{array}{l}-0.510 \\
(-1.38)\end{array}$ & & & $\begin{array}{l}-0.955^{* *} \\
(-2.08)\end{array}$ & $\begin{array}{l}-0.895^{* *} \\
(-2.00)\end{array}$ & & \\
\hline $\begin{array}{c}\text { Female- } \\
\text { perc }\end{array}$ & & & $\begin{array}{l}-3.100 \\
(-0.79)\end{array}$ & $\begin{array}{l}-3.404 \\
(-0.86)\end{array}$ & & & $\begin{array}{l}-11.43^{* *} \\
(-2.45)\end{array}$ & $\begin{array}{l}-10.51^{* *} \\
(-2.28)\end{array}$ \\
\hline Avage & $\begin{array}{l}-0.0623 \\
(-0.41)\end{array}$ & & $\begin{array}{l}-0.0555 \\
(-0.37)\end{array}$ & & $\begin{array}{l}-0.147 \\
(-0.91)\end{array}$ & & $\begin{array}{l}-0.170 \\
(-1.03)\end{array}$ & \\
\hline Yage & & $\begin{array}{l}1.758 * * \\
(2.14)\end{array}$ & & $\begin{array}{l}1.699 * * \\
(2.12)\end{array}$ & & $\begin{array}{l}0.650 \\
(0.62)\end{array}$ & & $\begin{array}{l}0.706 \\
(0.67)\end{array}$ \\
\hline Postgrad & $\begin{array}{l}0.853 * * * \\
(3.17)\end{array}$ & $\begin{array}{l}0.880 * * * \\
(3.24)\end{array}$ & $\begin{array}{l}0.833 * * * \\
(3.11)\end{array}$ & $\begin{array}{l}0.856 * * * \\
(3.16)\end{array}$ & $\begin{array}{l}1.089 * * * \\
(2.74)\end{array}$ & $\begin{array}{l}1.081^{* * * *} \\
(2.75)\end{array}$ & $\begin{array}{l}1.071^{* * * *} \\
(2.78)\end{array}$ & $\begin{array}{l}1.060 \text { *** } \\
(2.77)\end{array}$ \\
\hline $\mathrm{PhD}$ & $\begin{array}{l}0.430 * * \\
(2.27)\end{array}$ & $\begin{array}{l}0.424 * * \\
(2.03)\end{array}$ & $\begin{array}{l}0.397 * * \\
(2.06)\end{array}$ & $\begin{array}{l}0.390 * \\
(1.83)\end{array}$ & $\begin{array}{l}0.414 \\
(1.19)\end{array}$ & $\begin{array}{l}0.388 \\
(1.19)\end{array}$ & $\begin{array}{l}0.383 \\
(1.10)\end{array}$ & $\begin{array}{l}0.355 \\
(1.10)\end{array}$ \\
\hline LnNempl & $\begin{array}{l}-0.724 * * * \\
(-3.26)\end{array}$ & $\begin{array}{l}-0.698^{* * *} \\
(-3.02)\end{array}$ & $\begin{array}{l}-0.707 * * * \\
(-3.16)\end{array}$ & $\begin{array}{l}-0.679 * * * \\
(-2.92)\end{array}$ & $\begin{array}{l}-0.662^{* * *} \\
(-3.23)\end{array}$ & $\begin{array}{l}-0.654 * * * \\
(-3.20)\end{array}$ & $\begin{array}{l}-0.675^{* * *} \\
(-3.29)\end{array}$ & $\begin{array}{l}-0.663^{* * * *} \\
(-3.24)\end{array}$ \\
\hline Lev & $\begin{array}{l}-0.832 * * * \\
(-4.70)\end{array}$ & $\begin{array}{l}-0.781 * * * \\
(-4.26)\end{array}$ & $\begin{array}{l}-0.809 * * * \\
(-4.50)\end{array}$ & $\begin{array}{l}-0.758 * * * \\
(-4.07)\end{array}$ & $\begin{array}{l}-0.558^{* * * *} \\
(-3.61)\end{array}$ & $\begin{array}{l}-0.560 * * * \\
(-3.46)\end{array}$ & $\begin{array}{l}-0.535^{* * *} \\
(-3.38)\end{array}$ & $\begin{array}{l}-0.541 \text { *** } \\
(-3.32)\end{array}$ \\
\hline ROE & $\begin{array}{l}3.403 * * * \\
(3.98)\end{array}$ & $\begin{array}{l}3.188^{* * * *} \\
(3.88)\end{array}$ & $\begin{array}{l}3.316^{* * * *} \\
(3.79)\end{array}$ & $\begin{array}{l}3.113^{* * * *} \\
(3.70)\end{array}$ & $\begin{array}{l}-1.281 \\
(-0.65)\end{array}$ & $\begin{array}{l}-1.787 \\
(-0.92)\end{array}$ & $\begin{array}{l}-1.227 \\
(-0.62)\end{array}$ & $\begin{array}{l}-1.831 \\
(-0.94)\end{array}$ \\
\hline $\begin{array}{c}\text { Owner- } \\
\text { ship }\end{array}$ & $\begin{array}{l}-0.810 \\
(-0.51)\end{array}$ & $\begin{array}{l}-0.871 \\
(-0.57)\end{array}$ & $\begin{array}{l}-0.856 \\
(-0.54)\end{array}$ & $\begin{array}{l}-0.929 \\
(-0.61)\end{array}$ & $\begin{array}{l}-1.228 \\
(-0.77)\end{array}$ & $\begin{array}{l}-0.953 \\
(-0.55)\end{array}$ & $\begin{array}{l}-1.369 \\
(-0.86)\end{array}$ & $\begin{array}{l}-1.043 \\
(-0.60)\end{array}$ \\
\hline Region & $\begin{array}{l}2.328 * * \\
(1.96)\end{array}$ & $\begin{array}{l}2.530 * * \\
(2.06)\end{array}$ & $\begin{array}{l}2.549 * * \\
(2.11)\end{array}$ & $\begin{array}{l}2.765^{* *} \\
(2.21)\end{array}$ & $\begin{array}{l}3.171 * * \\
(2.41)\end{array}$ & $\begin{array}{l}3.214 * * \\
(2.37)\end{array}$ & $\begin{array}{l}3.128^{* *} \\
(2.46)\end{array}$ & $\begin{array}{l}3.184 * * \\
(2.44)\end{array}$ \\
\hline Industry & $\begin{array}{l}0.348 \\
(0.31)\end{array}$ & $\begin{array}{l}0.363 \\
(0.33)\end{array}$ & $\begin{array}{l}0.297 \\
(0.26)\end{array}$ & $\begin{array}{l}0.316 \\
(0.28)\end{array}$ & $\begin{array}{l}3.171^{* *} \\
(2.41)\end{array}$ & $\begin{array}{l}3.214^{* *} \\
(2.37)\end{array}$ & $\begin{array}{l}3.128 * * \\
(2.46)\end{array}$ & $\begin{array}{l}3.184 * * \\
(2.44)\end{array}$ \\
\hline $\begin{array}{l}\text { Year } \\
\text { effect }\end{array}$ & Yes & Yes & Yes & Yes & Yes & Yes & Yes & Yes \\
\hline Intercept & $\begin{array}{l}32.69 * * * \\
(3.64)\end{array}$ & $\begin{array}{l}27.73 * * * \\
(9.89)\end{array}$ & $\begin{array}{l}32.89 * * * \\
(3.65)\end{array}$ & $\begin{array}{l}28.40^{* * * *} \\
(9.05)\end{array}$ & $\begin{array}{l}37.95 * * * \\
(4.17)\end{array}$ & $\begin{array}{l}29.30 * * * \\
(10.97)\end{array}$ & $\begin{array}{l}41.67 * * * \\
(4.58)\end{array}$ & $\begin{array}{l}31.50 * * * \\
(11.51)\end{array}$ \\
\hline $\mathrm{Nr}$ of obs & 188 & 188 & 188 & 188 & 141 & 141 & 141 & 141 \\
\hline $\begin{array}{l}\mathrm{Nr} \text { of } \\
\text { groups }\end{array}$ & 47 & 47 & 47 & 47 & 47 & 47 & 47 & 47 \\
\hline Wald $X^{2}$ & 271.01 & 264.32 & 264.48 & 258.06 & 321.65 & 278.04 & 357.34 & 287.88 \\
\hline Prob $>X^{2}$ & 0.0000 & 0.0000 & 0.0000 & 0.0000 & 0.0000 & 0.0000 & 0.0000 & 0.0000 \\
\hline $\mathrm{R}^{2}$ overall & 0.4230 & 0.4328 & 0.4187 & 0.4283 & 0.4320 & 0.4285 & 0.4405 & 0.4353 \\
\hline
\end{tabular}


Table 10 (continued)

This table presents the results of a Random Effect Panel Regression (model 1) with no endogeneity corrections (columns A to D), of a Random Effect Panel Regression(Model 2) with lagged firm-specific variables as a treatment for endogeneity (columns $\mathrm{E}$ to $\mathrm{H}$ ) Heteroskedasticity consistent (robust) standard errors are used to compute $\mathrm{z}$ statistics. *,**, and *** denote significance at the 10,5 , and $1 \%$ levels, respectively. The Sample excludes South-Africa where IR is compulsory

HP4 The higher the level of education of Board members, the more the quality of IR improves.

We find a positive (ranging from +0.793 to +0.897 ) and significant (at $10 \%$ and 5\%) coefficient for postgraduate studies (Table 9-columns $\mathrm{E}$ to $\mathrm{H}$ ). The same occurs considering the sample without countries where IR is mandatory, but with a significance level of $1 \%$ (Table 10-columns E to $\mathrm{H}$ ).

For $\mathrm{PhD}$ studies, model 1 shows positive and significant coefficients in both Tables 9 and 10 but those results are not confirmed in model 2, where the coefficients, although positive, are not significant.

According to our results, we can reasonably state that HP4 is supported: a higher level of education of board members improves the quality of the IR.

HP5 The lower the average age of Board members, the more the quality of IR improves.

We observe a significant (at 0.10 ) and negative (respectively -0.254 and -0.268 ) coefficient for the variable Average (columns E and G) and a positive but not significant coefficient for the variable Yage in columns F and H. Looking at Table 10 we find a not significant coefficient for all the equations (columns $\mathrm{E}$ to $\mathrm{H}$ ).

Considering these results, we can say that HP5 is not supported.

In conclusion, our results reasonably suggest that there is a significant but negative relationship between the presence of women on the board and the quality of the disclosure, while it is possible to identify a positive effect of education of board members on IR quality.

On the other hand, we cannot confirm that the size of the board, the number of nonexecutive members and younger age can have an impact on IR quality (Fig. 3).

Concerning control variables, firm size, ownership region and industry are not significant, even considering the logarithm of total assets instead of total employees as a proxy for firm size, while leverage is significant in all models, but with a negative sign, and ROE (with a positive sign) is significant, but only in model 1. Looking at Table 10 (columns $\mathrm{E}$ to $\mathrm{H}$ ) ownership is not significant, ROE is significant, but only in model 1, while leverage and firm size are significant with a negative sign. Moreover, region and industry are also significant (with a positive sign).

In conclusion, our results reasonably suggest that there is a significant but negative relationship between the presence of women on the board and the quality of the disclosure, while it is possible to identify a positive effect of education of board members on IR quality. 
Theory
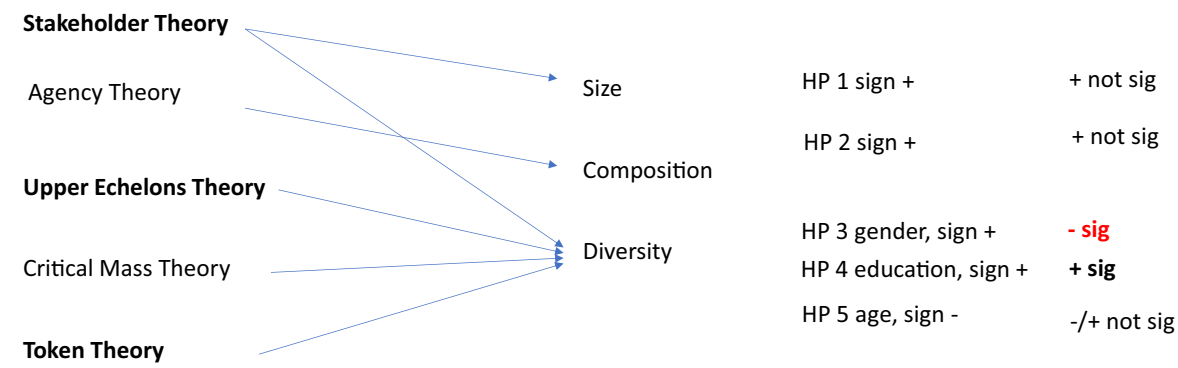

Fig. 3 Board characteristics and theories, according to our findings

On the other hand, we cannot confirm that the size of the board, the number of nonexecutive members and younger age can have an impact on IR quality (Fig. 3).

Concerning control variables, firm size, ownership region and industry are not significant, even considering the logarithm of total assets instead of total employees as a proxy for firm size, while leverage is significant in all models, but with a negative sign, and ROE (with a positive sign) is significant, but only in model 1. Looking at Table 10 (columns $\mathrm{E}$ to $\mathrm{H}$ ) ownership is not significant, ROE is significant, but only in model 1 , while leverage and firm size are significant with a negative sign. Moreover, region and industry are also significant (with a positive sign).

\section{Conclusions}

This paper aimed to deal with the determinants of IR quality, with particular regard to board characteristics. Non-financial disclosure is gaining more and more attention on the part of companies, academia and Institutions (see the Directive 2014/95/EU). However, the quality of the disclosure to stakeholders represents a critical issue, especially in the case of voluntary non-financial disclosure, characterized by many different standards, tools and mechanisms.

In the field of voluntary disclosure, IR is the most recent tool designed to improve the understanding of a company's ability to create value over time. However, IR is still not widespread enough and its quality is usually low because of some critical issues (Pistoni et al. 2018): the absence of connectivity between strategy, business model, performance, and outlook; the limited presence of descriptions, diagrams and maps; the absence of information related to corporate governance, the relationship with the stakeholders and the materiality process; the inadequate description of the business model; and the scarce use of external audit practices.

All these aspects show that the quality of IR still represents a significant issue to deal with.

The quality of disclosure may be guaranteed by leveraging on its determinants, including corporate governance. Previous studies on both voluntary disclosure and IR actually suggest that the board could have a relevant role in determining and 
affecting not only disclosure quality, but also IR quality (Haniffa \& Cooke, 2005; Harjoto et al. 2015; Vitolla et al. 2020a, 2020b). Although the quality of both disclosure and IR represents a relevant issue for both academia and practice, only a few studies have so far dealt with it, without proposing a shared theoretical framework and with conflicting findings.

This paper has therefore pursued the objective of identifying the variables that could influence IR quality with particular regard to the board's characteristics. Based on a preliminary literature review, some possible determinants of IR quality related to board characteristics were identified: board size, number of independent members, the presence of women, the age and the level of education of board members. We then developed five hypotheses regarding the association between these determinants and IR quality.

For the evaluation of IR quality we referred to the IRS proposed by Pistoni et al. (2018). 53 companies were taken into consideration from 2013 to 2016 for a total number of 212 integrated reports. Then Random Effect panel regression analysis with lagged explanatory variables was used to test the relationship between the independent variables, control variables (firm size, leverage, profitability, industry type, region and ownership) and the content disclosure score, which is our dependent variable, controlling for endogeneity issues.

Our research findings reveal that the quality of IR is positively associated with the level of education of board members and firm's profitability (ROE) (Model 1). We found a significant effect of women on the board, but with a negative coefficient. Leverage is significant in all models, but with a negative sign. Moreover, if we exclude from our sample companies operating in South Africa (where the adoption of IR is mandatory), the facts of not operating in an Anglo-Saxon country and not in the manufacturing industry, together with firm size (with a negative sign) also represent significant determinants of IR quality.

Our findings confirm some previous contributions in the literature (Lewis et al. 2014; Raman \& Bukair, 2013; Yasser et al. 2017).

With regard to the level of education of board members, our results support Lewis et al. (2014) who found a positive influence of a high level of education of the CEO on the amount of environmental performance disclosure. When they highlight a significant role of board characteristics, with regard to board members' education, our findings are supported by stakeholder theory; in fact, skilled board members may better guarantee the stakeholders' interests due to their higher qualification.

We found a significant effect of women on the board, but with a negative coefficient, contrary to expectations. These findings are not aligned with most previous literature that generally shows a positive impact of women on disclosure, while they confirm results of studies that proposed a negative association (Cucari et al. 2018; Fasan \& Mio, 2017; Lorenzo et al. 2009; Shamil et al. 2014). Interestingly, if we consider only countries where IR is not mandatory, our findings also show that only with a critical mass of 3 women on the board does the impact on IR quality become more significant, although its sign remains negative. These findings seem to be supported more by Token theory (Kanter, 1977b; Nielsen \& Huse, 2010) than Critical mass theory (Carver, 2002; Cassell, 2000), as they underline that women on the board have difficulties in effectively contributing to 
board decisions in terms of IR quality. In fact, in our sample female members of the board represent only $21.53 \%$ of total members and they are mostly nonexecutive members, highlighting a typical situation of tokenism. Moreover, they have a lower level of education (only a few women have a PhD or an MBA) and they are graduates mostly in social sciences and humanities. Thus, it may be that there is an inadequate selection of female members of the board, and so the negative sign could be explained also by the quality of women's competencies rather than simply by their number. The fact that the majority of women are independent directors may also explain the negative association with IR quality, as it is consistent with the findings of some authors (Alnabsha et al. 2018; Prado-Lorenzo \& García-Sánchez, 2010), who found a negative relationship between the board composition in terms of the number of independent members and the overall corporate disclosure level. Another explanation could be found in the work of Adams and Ferreira (2009). In their study on the relationship between women in boardrooms and performance, they found no general evidence of a positive impact on performance of women's presence on boards, except in companies with weak governance. We may assume, in this sense, that our sample companies did not show the weaknesses in governance which can allow these companies to leverage women's presence on their boards. Furthermore, in our sample a more than $30 \%$ average of women board members can be found in listed firms operating in Europe and in particular in the UK and in financial services and other services. Thus, we may suppose that women, in our sample firms, tend to be appointed to boards in countries and industries that are more evolved in terms of governance structures, while other national contexts and manufacturing industries have less diverse and more traditional governance systems, where it is difficult for women to be present and make a contribution. Our findings are consistent with those studies which support the view that the effectiveness of independent members may depend on the institutional systems and business cultures in which a company operates (Kakabadse et al. 2010). On the other hand, the number of European countries in our sample may also allow us to suppose that in most companies of our sample women are appointed to the board following a legal requirement, that requires the introduction of quotas for women, instead of considering their experience and competencies.

We can confirm a negative association also with leverage, consistently with previous studies (Bavagnoli et al. 2018; Cormier \& Magnan, 2003). The negative relation between a high level of leverage and propensity to disclose higher quality IR can be explained by the fact that firms with high debt are not willing to disclose potentially damaging information.

On the other hand, we could not confirm associations found in previous literature between the quality of the disclosure and board size, number of nonexecutive members, and the age of board members. We did, however, find previous studies that found no relation (for example for the board size: Uyar et al. 2014; Kiliç \& Kuzey, 2018; for the number of nonexecutive members: Kakabadse et al. 2010; Elzahar \& Hussainey, 2012; Uyar \& Kiliç, 2012).

Concerning the age of board members, our findings are not consistent with those of Katmon et al. (2019), who highlighted a negative association between board age 
and the quality of CSR disclosure, and with those of Alfiero et al. (2017), who found that the presence of older directors on the board negatively affects IR adoption.

Moreover, with regard to control variables, firm size, region and industry are not significant if we consider the whole sample, while they become significant if South African companies are dropped.

Our results seem to support the idea that the "quality" of the board members matters more than their "quantity" in increasing IR quality, and that diversity in the board, meaning differences in the directors' characteristics, is more relevant than diversity of the board, related to differences in the board's formal structure (size and composition) (Hafsi \& Turgut, 2013). In this way, our findings are consistent with Upper Echelons theory, which proposes that organizational outcomes are related to background characteristics of the management team and board members, such as gender and education (Hambrick \& Mason, 1984).

This paper provides some important contributions to IR research. Firstly, it goes deeper into under-developed issues, such as the determinants of IR quality. Secondly, it aims to identify some significant determinants of IR quality related to board characteristics and this could be a starting point for future research. Thirdly, we critically interpreted our findings referring to several theories, thus contributing to theoretical advancement in the field. In particular, given the diversity and number of independent variables considered in our study and our research aims, we proved that one specific theory cannot be sufficient to understand such complex relations, but that a wider set of theories is needed to go deeper into the impact that different board characteristics may have on IR quality. In particular, our findings are supported by stakeholder theory, upper echelons theory and token theory. These theories constitute the main theoretical reference streams in explaining the relations between board diversity and IR quality (Fig. 3). This represents a theoretical advancement as most previous studies refer only to one or very few theories to explain their research findings on the relation between Board features and the quality of disclosure and IR.

There are also some implications for practitioners and institutions. Considered as a whole, our findings suggest that to obtain an efficient board, its members should be selected on the basis of the level of education and competencies. Moreover, it is not necessary to introduce policies to increase the number of women, who should also be selected on the basis of their personal competencies. Considering the characteristics which may explain differences between board members, those related to education and skills seem to be more relevant, maybe as a wide range of knowledge and skills fosters different perspectives and ideas, and more innovative approaches to boards (Harjoto et al. 2015). These aspects may favor the increase of IR quality, as IR represents a relatively new and complex tool that requires the development of an integrated way of thinking, which is very different from traditional approaches to disclosure.

Our research findings support the need for firms to define a diverse board with regard to gender, but not as a consequence of a compulsory decision, forced by regulations and roles (i.e. quotas), or to gain legitimacy with stakeholders (Fasan \& Mio, 2017). The involvement of women on the board should follow a proactive firm decision, aimed at having skilled and well-educated women on the board in order to leverage their specific contributions. 
Our research has some limitations related to the kind of methodology applied: there could be a problem of subjectivity in the content analysis phase (de Villiers et al. 2017; Hammond \& Miles, 2004; Krippendorff, 1980), even though it has been performed by two researchers who autonomously applied the research protocol after proper training. Moreover, we considered only integrated reports available on the 'Getting Started' section of the IR examples website, but it is possible that other companies prepared an integrated report without publishing it on the IIRC website. However, it should be noted that the IIRC database can be considered the most relevant source of information on IR. A possible limitation related to the sample selection may concern the fact that the sample includes companies that are considered best practices by the IIRC; this could affect the generalization of the results to enterprises that are not best practices in the adoption of IR. The analysis of a wider sample of integrated reports downloaded from sources other than the IIRC database could help to deal with this issue, even though it may be very difficult to find other relevant sources from which to select a significant sample of integrated reports.

A further limitation of our study concerns the definition and measurement of our dependent variable, as we referred specifically to the Integrated Reporting Scoreboard (IRS) proposed by Pistoni et al. (2018) and in particular to its Content area. The use of other measures of IR quality could have led to different findings.

Furthermore, even though we have considered a great number of control variables, we did not use all variables suggested by the literature on the board (Kanageretnam et al. 2007; Lipton \& Lorsh, 1992), such as the influence of the field of interest of the board members. These variables could be analyzed in future research.

Finally, some suggestions for future research should include the analysis over a longer period of time and a more in-depth study of the relationship between the presence of female members on the Board by considering their characteristics (number, age, role, level of education, field of interest and so on) and the quality of Integrated Reporting. Moreover, as said above, it could also be interesting to consider a broader sample of integrated reports selected from new sources other than the IIRC database. Again, previous literature on the board of directors suggests studying the impacts of other variables on the quality of the disclosure, such as the field of interest of the board members. Finally, future research could improve and test our theoretical framework in order to better identify which theories are best suited to explain how board characteristics can affect the quality of IR.

Acknowledgements The authors acknowledge Libero Istituto Universitario C.Cattaneo (LIUC) for the financial support given to their research project. They acknowledge also University of Eastern Piedmont for the financial support (FAR 2017).

Funding Open access funding provided by Università degli Studi del Piemonte Orientale Amedeo Avogrado within the CRUI-CARE Agreement.

Open Access This article is licensed under a Creative Commons Attribution 4.0 International License, which permits use, sharing, adaptation, distribution and reproduction in any medium or format, as long as you give appropriate credit to the original author(s) and the source, provide a link to the Creative Commons licence, and indicate if changes were made. The images or other third party material in this article are included in the article's Creative Commons licence, unless indicated otherwise in a credit line to the material. If material is not included in the article's Creative Commons licence and your intended use is 
not permitted by statutory regulation or exceeds the permitted use, you will need to obtain permission directly from the copyright holder. To view a copy of this licence, visit http://creativecommons.org/licen ses/by/4.0/.

\section{References}

Abatecola, G., \& Cristofaro, M. (2018). Hambrick and Mason's "Upper Echelons Theory”: evolution and open avenues. Journal of Management History, 26(1), 116-136.

Åberg, C., \& Torchia, M. (2019). Do boards of directors foster strategic change? A dynamic managerial capabilities perspective. Journal of Management \& Governance, 24, 1-30.

Abeysekera, I. (2010). The influence of board size on intellectual capital disclosure by Kenyan listed firms. Journal of intellectual capital, 11(4), 504-518.

Abeysekera, I. (2013). A template for integrated reporting. Journal of Intellectual Capital, 14(2), $227-245$.

Adams, C. A. (2002). Internal organizational factors influencing corporate social and ethical reporting. Accounting, Auditing \& Accountability Journal, 15(2), 223-250.

Adams, R. B., Almeida, H., \& Ferreira, D. (2005). Powerful CEOs and their impact on corporate performance. The Review of Financial Studies, 18(4), 1403-1432.

Adams, R. B., \& Ferreira, D. (2009). Women in the boardroom and their impact on governance and performance. Journal of financial economics, 94(2), 291-309.

Adams, R. B., Hermalin, B. E., \& Weisbach, M. S. (2010). The role of boards of directors in corporate governance: a conceptual framework and survey. Journal of Economic Literature, 48(1), 58-107.

Aggarwal, R. K., \& Nanda, D. (2004). Access, common agency, and board size. SSRN Journal. https:// doi.org/10.2139/ssrn.571801

Ajinkya, B., Bhojraj, S., \& Sengupta, P. (2005). The association between outside directors, institutional investors and the properties of management earnings forecasts. Journal of Accounting Research, 43(3), 343-376.

Akhtaruddin, M., Hossain, M. A., Hossain, M., \& Yao, L. (2009). Corporate governance and voluntary disclosure in corporate annual reports of Malaysian listed firms. Journal of Applied Management Accounting Research, 7(1), 1-19.

Al-Najjar, B., \& Abed, S. (2014). The association between disclosure of forward-looking information and corporate governance mechanisms: evidence from the UK before the financial crisis period. Managerial Auditing Journal, 29(7), 578-595.

Alfiero, S., Cane, M., Doronzo, R., \& Esposito, A. (2017). Board configuration and IR adoption. Empirical evidence from European companies. Corporate Ownership \& Control, 15(1), 444-458.

Alfiero, S., Cane, M., Doronzo, R., \& Esposito, A. (2018). Determining characteristics of boards adopting Integrated Reporting. Financial Reporting, 2, 37-71.

Alfraih, M. M. (2018). What drives intellectual capital reporting? Evidence from Kuwait. International Journal of Productivity and Performance Management, 67(3), 571-589.

Allini, A., Manes Rossi, F., \& Hussainey, K. (2016). The board's role in risk disclosure: an exploratory study of Italian listed state-owned enterprises. Public Money \& Management, 36(2), 113-120.

Alnabsha, A., Abdou, H. A., Ntim, C. G., \& Elamer, A. A. (2018). Corporate boards, ownership structures and corporate disclosures: Evidence from a developing country. Journal of Applied Accounting Research, 19(1), 20-41.

Amason, A. C. (1996). Distinguishing the Effects of Functional and Dysfunctional Conflict on Strategic Women Directors on Corporate Boards 313 Decision Making: Resolving a Paradox for Top Management Teams. Academy of Management Journal, 39(1), 123-148.

Ameer, R., Ramli, F., \& Zakaria, H. (2010). A new perspective on board composition and firm performance in an emerging market. Corporate Governance: The International Journal of Business in Society, 10(5), 647-661.

Amorelli, M. F., \& García-Sánchez, I. M. (2020). Critical mass of female directors, human capital, and stakeholder engagement by corporate social reporting. Corporate Social Responsibility and Environmental Management, 27(1), 204-221. 
Amran, A., \& Haniffa, R. (2011). Evidence in Development of Sustainability Reporting: a Case of a Developing Country. Business Strategy and the Environment, 20, 141-156.

Amran, N. A., \& Manaf, K. B. A. (2014). Board independence and accounting conservatism in Malaysian companies. Procedia-Social and Behavioral Sciences, 164, 403-408.

Bantel, K. A., \& Jackson, S. E. (1989). Top management and innovations in banking: Does the composition of the top team make a difference? Strategic Management Journal, 10, 107-124.

Bar-Yosef, S., \& Prencipe, A. (2009). Earnings management and corporate governance in family-controlled companies. SSRN. https://doi.org/10.2139/ssrn.1367543

Barako, D. G., \& Brown, A. M. (2008). Corporate social reporting and board representation: evidence from the Kenyan banking sector. Journal of Management \& Governance, 12(4), 309-324.

Bavagnoli F, Minutiello, V., Pistoni A., and Songini L. (2018). The determinants of integrated reporting quality: an empirical analysis, paper presented at the 2018 EURAM Conference.

Bear, S., Rahman, N., \& Post, C. (2010). The impact of board diversity and gender composition on corporate social responsibility and firm reputation. Journal of Business Ethics, 97(2), 207-221.

Becker, M. H. (1970). Sociometric location and innovativeness: Refor-mulation and extension of the diffusion model. American Sociological Review, 35, 267-304.

Bekiroglu, C., Erdil, O., \& Alkpan, L. (2011). Variables perceived by managers as antecedents that leads firms to environmental management: An empirical research in the Turkish construction sector. Journal of Global Strategic Management, 9, 157-174.

Bellemare, M. F., Masaki, T., \& Pepinsky, T. B. (2017). Lagged Explanatory Variables and the Estimation of Causal Effect. The Journal of Politics, 79(3), 949-963.

Ben-amar, W., Chang, M., \& Mcilkenny, P. (2017). Board gender diversity and corporate response to sustainability initiatives: Evidence from the carbon disclosure project: JBE JBE. Journal of Business Ethics, 142(2), 369-383.

Beretta, V., Demartini, M. C., \& Trucco, S. (2020). Tone at Top in Integrated Reporting: The Role of Non-Financial Performance. Practices and Critical Issues. Emerald Publishing Limited.

Bernardi, R., Bosco, S., \& Vassill, K. (2006). Does female representation on boards of directors associate with Fortune's 100 best companies to work for list? Business \& Society, 45(2), 235-248.

Boesso, G., \& Kumar, K. (2007). Drivers of corporate voluntary disclosure: A framework and empirical evidence from Italy and the United States. Accounting, Auditing \& Accountability Journal, 20(2), 269-296.

Bonn, I., Yoshikawa, T., \& Phan, P. H. (2004). Effects of board structure on firm performance: A comparison between Japan and Australia. Asian Business \& Management, 3(1), 105-125.

Boulouta, I. (2013). Hidden connections: the link between Board gender diversity and corporate social performance. Journal of Business Ethics, 113(2), 185-197.

Busco, C., Malafronte, I., Pereira, J., \& Starita, M. G. (2019). The determinants of companies' levels of integration: Does one size fit all? The British Accounting Review, 51(3), 277-298.

Carpenter, M. A., Geletkanycz, M. A., \& Sanders, G. W. (2004). Upper Echelons Research Revisited: Antecedents, Elements, and Consequences of Top Management Team Composition. Journal of Management, 30(6), 749-778.

Carter, D. A., Simkins, B. J., \& Simpson, W. G. (2003). Corporate governance, board diversity, and firm value. Financial review, 38(1), 33-53.

Carver, J. (2002). John Carver on board leadership: Selected writings from the creator of the world's most provocative and systematic governance model. Jossey-Bass.

Cassell, C. (2000). Managing Diversity in the New Millennium. Personnel Review, 29(3), 268-274.

Cerbioni, F., \& Parbonetti, A. (2007). Exploring the effects of corporate governance on intellectual capital disclosure: An analysis of European biotechnology companies. European Accounting Review, 16(4), 791-826.

Cheng, E. C. M., \& Courtenay, S. M. (2006). Board composition, regulatory regime and voluntary disclosure. The International Journal of Accounting, 41(3), 262-289.

Child, J. (1974). Managerial and organizational factors associated with company performance. Journal of Management Studies, 11, 13-27.

Coffey, B. S., \& Wang, J. (1998). Board diversity and managerial control as predictors of corporate social performance. Journal of Business Ethics, 17(14), 1595-1603.

Cook, A., \& Glass, C. (2017). Women on corporate boards: Do they advance corporate social responsibility? Human relations, 71(7), 897-924.

Cormier, D., \& Magnan, M. (2003). Environmental reporting management: a continental European perspective. Journal of Accounting and Public Policy, 22(1), 43-62. 
Cucari, N., Esposito De Falco, S., \& Orlando, B. (2018). Diversity of board of directors and environmental social governance: Evidence from Italian listed companies. Corporate Social Responsibility and Environmental Management, 25(3), 250-266.

Dah, M., Al-Dah, B., \& Jizi, M. (2018). Is CSR reporting always favorable? Management Decision, $56(7), 1506-1525$.

Dalton, D., Johnson, J., \& Ellstrand, A. (1999). Number of directors and financial performance: A metaanalysis. Academy of Management Journal, 42(6), 674-686.

De Villiers, C., Venter, E. R., \& Hsiao, P. C. K. (2017). Developing a Conceptual Model of influences around Integrated Reporting, New Insights, and Directions for Future Research. Meditari Accountancy Research, 25(4), 450-460.

Dilling, P. F. A., \& Caykoylu, S. (2019). Determinants of Companies that Disclose High-Quality Integrated Reports. Sustainability, 11, 3744.

Du Toit, A. D., Steyn, B., Pilley, A., \& Gweshe, R. (2014). Insights into SOC Integrated Reporting Trends in South Africa. Journal of Management Research, 7(3), 130-156.

Dumay, J., Bernardi, C., Guthrie, J., \& Demartini, P. (2016). Integrated reporting: a structured literature review. Accounting Forum, 40(3), 166-185.

Dumay, J., Bernardi, C., Guthrie, J., \& La Torre, M. (2017). Barriers to implementing the international integrated reporting framework: a contemporary academic perspective. Meditari Accountancy Research, 25(4), 461-480.

Eagly, A. H., Johannesen-Schmidt, M. C., \& van Engen, M. L. (2003). Transformational, transactional, and Laissez-Faire leadership styles: A meta-analysis comparing women and men. Psychological Bulletin, 129(4), 569-591.

Eagly, A. H., \& Johnson, B. T. (1990). Gender and leadership style: A meta-analysis. Psychological Bulletin, 108(2), 233-256.

Elzahar, H., \& Hussainey, K. (2012). Determinants of narrative risk disclosures in UK interim reports. The Journal of Risk Finance, 13(2), 133-147.

Eng, L. L., \& Mak, Y. T. (2003). Corporate governance and voluntary disclosure. Journal of Accounting and Public Policy, 22(4), 325-345.

Fama, E. F., \& Jensen, M. (1983). Separation of ownership and control. Journal of Law and Economics, 26(2), 301-326.

Fasan, M., \& Mio, C. (2017). Fostering stakeholder engagement: The role of materiality disclosure in integrated reporting. Business Strategy and the Environment, 26(3), 288-305.

Fernandez-Feijoo, B., Romero, S., \& Ruiz-Blanco, S. (2014). Women on boards: do they affect sustainability reporting? Corporate Social Responsibility and Environmental Management, 21(6), 351-364.

Fiori, G., di Donato, F., \& Izzo, M. F. (2016). Exploring the Effects of Corporate Governance on Voluntary Disclosure: An Explanatory Study on the Adoption of Integrated Report. Performance Measurement and Management Control: Contemporary Issues, 31, 83-108.

Frías-Aceituno, J. V., Rodríguez-Ariza, L., \& García-Sánchez, I. M. (2012). The role of the board in the dissemination of integrated corporate social reporting. Corporate Social Responsibility and Environmental Management, 20(4), 219-233.

Frías-Aceituno, J. V., Rodríguez-Ariza, L., \& García-Sánchez, I. M. (2013). Is integrated reporting determined by a country's legal system? An exploratory study. Journal of Cleaner Production, 44, 45-55.

Fuente, J. A., Garcia-Sanchez, I. M., \& Lozano, M. B. (2017). The role of the board of directors in the adoption of GRI guidelines for the disclosure of CSR information. Journal of Cleaner Production, 141(10), 737-750.

Gallego-Alvarez, I., Manuel Prado-Lorenzo, J., \& García-Sánchez, I. M. (2011). Corporate social responsibility and innovation: A resourcebased theory. Management Decision, 49(10), 1709-1727.

Gandía, J. L. (2008). Determinants of internet-based corporate governance disclosure by Spanish listed companies. Online Information Review, 32(6), 791-817.

García-Sánchez, I. M., Martínez-Ferrero, J., \& Garcia-Benau, M. A. (2019). Integrated reporting: The mediating role of the board of directors and investor protection on managerial discretion in munificent environments. Corporate Social Responsibility and Environmental Management, 26(1), 29-45.

García-Sánchez, I. M., Rodríguez Domínguez, L., \& Gallego Alvarez, I. (2011). Corporate governance and strategic information on the internet: A study of Spanish listed companies. Accounting, Auditing \& Accountability Journal, 24(4), 471-501. 
Gerwanski, J., Kordsachia, O., \& Velte, P. (2019). Determinants of materiality disclosure quality in integrated reporting: Empirical evidence from an international setting. Business Strategy and the Environment, 28(5), 750-770.

Giannarakis, G. (2014a). The determinants influencing the extent of CSR disclosure. International Journal of Law and Management, 56(5), 393-416.

Giannarakis, G. (2014b). Corporate governance and financial characteristic effects on the extent of corporate social responsibility disclosure. Social Responsibility Journal, 10(4), 569-590.

Giannarakis, G., Konteos, G., \& Sariannidis, N. (2014). Financial, governance and environmental determinants of corporate social responsible disclosure. Management Decision, 52(10), 1928-1951.

Granovetter, M. (1978). Threshold Models of Collective Behavior. American Journal of Sociology, 83(6), 1420-1443.

Guthrie, J., \& Parker, L. (1990). Corporate social disclosure practice: a comparative international analysis. Advances in public interest accounting, 3, 159-175.

Hafsi, T., \& Turgut, G. (2013). Boardroom diversity and its effect on social performance: Conceptualization and empirical evidence. Journal of business ethics, 112(3), 463-479.

Hambrick, D. C. (2007). Upper echelons theory: An update. Academy of Management Review. https://doi. org/10.5465/amr.2007.24345254

Hambrick, D. C., Cho, T. S., \& Chen, M. J. (1996). The influence of top management team heterogeneity on firms' competitive moves. Administrative science quarterly, 41, 659-684.

Hambrick, D. C., \& Mason, P. A. (1984). Upper Echelons: The Organization as a Reflection of Its Top Managers. The Academy of Management Review, 9(2), 193-206.

Hammond, K., \& Miles, S. (2004). Assessing quality assessment of corporate social reporting: UK perspectives. Accounting Forum, 28(1), 61-79.

Haniffa, R. M., \& Cooke, T. E. (2005). The impact of culture and governance on corporate social reporting. Journal of Accounting and Public Policy, 24(5), 391-430.

Harjoto, M., Laksmana, I., \& Lee, R. (2015). Board diversity and corporate social responsibility. Journal of Business Ethics, 132(4), 641-660.

Hart, P., \& Mellons, J. (1970). Management youth and company growth: A correlation? Management Decision, 4(2), 50-53.

Hassan, R., Marimuthu, M., \& Johl, S. K. (2015). Diversity, corporate governance and implication on firm financial performance. Global Business and Management Research, 7(2), 28-36.

Hassan, R., Marimuthu, M., \& Johl, S. K. (2017). Bridging and bonding: How gender diversity influence organizational performance. Global Business and Management Research, 9(1), 117-126.

Havlová, K. (2015). What integrated reporting changed: the case study of early adopters. Procedia Economics and Finance, 34, 231-237.

Haynes, K. T., \& Hillman, A. J. (2010). The effect of board capital and CEO power on strategic change. Strategic Management Journal, 31, 1145-1163.

Healy, J. (2002). Corporate governance \& wealth creation in New Zealand. Dunmore Press Ltd.

Healy, P. M., \& Palepu, K. G. (2001). Information asymmetry, corporate disclosure, and the capital markets: A review of the empirical disclosure literature. Journal of Accounting and Economics, 31, $405-440$.

Hermalin, B. E., \& Weisbach, M. S. (1998). Endogenously chosen boards of directors and their monitoring of the CEO. American Economic Review, 88(1), 96-118.

Hidalgo, R. L., García-Meca, E., \& Martínez, I. (2011). Corporate governance and intellectual capital disclosure. Journal of Business Ethics, 100(3), 483-495.

Hillman, A. J., Cannella, A. A., Jr., \& Harris, I. C. (2002). Women and racial minorities in the boardroom: How do directors differ? Journal of Management, 28, 747-763.

Hoffman, L. R. (1959). Homogeneity of Member Personality and Its Effect on Group Problem Solving. Journal of Abnormal and Social Psychology, 58(1), 27-32.

Hoffman, L. R., \& Maier, N. R. F. (1961). Quality and Acceptance of Problem Solutions by Members of Homogeneous and Heterogeneous Groups. Journal of Abnormal and Social Psychology, 62(2), 401-407.

Horner, S. V. (2009). Board power, CEO appointments, and CEO duality. Allied Academies International Conference.Academy of Strategic Management.Proceedings, 8(1), 25-30.

Hossain, M., \& Reaz, M. (2007). The determinants and characteristics of voluntary disclosure by Indian banking companies. Corporate Social Responsibility and Environmental Management, 14(5), $274-288$. 
Hyun, E., Yang, D., Jung, H., \& Hong, K. (2016). Women on boards and corporate social responsibility. Sustainability, 8(4), 300.

Isidro, H., \& Sobral, M. (2015). The effects of women on corporate boards on firm value, financial performance, and ethical and social compliance. Journal of Business Ethics, 132(1), 1-19.

Jizi, M. I., Salama, A., Dixon, R., \& Stratling, R. (2014). Corporate governance and corporate social responsibility disclosure: evidence from the US banking sector. Journal of Business Ethics, 125(4), $601-615$.

John, K., \& Senbet, L. W. (1998). Corporate governance and board effectiveness. Journal of banking \& Finance, 22(4), 371-403.

Johnson, R. A., \& Greening, D. W. (1999). The effects of corporate governance and institutional ownership types on corporate social performance. Academy of Management Journal, 42(5), 564-576.

Kakabadse, N. K., Yang, H., \& Sanders, R. (2010). The effectiveness of nonexecutive directors in Chinese state-owned enterprises. Management Decision, 48(7), 1063-1079.

Kanagaretnam, K., Lobo, G. J., \& Whalen, D. J. (2007). Does good corporate governance reduce information asymmetry around quarterly earnings announcement? Journal of Accounting and Public Policy, 26(4), 497-522.

Kanter, R. M. (1977a). Men and Women of the Corporation. Basic Books.

Kanter, R. M. (1977b). Some Effects of Proportions on Group Life. American Journal of Sociology, 82(5), 965-990.

Kanter, R. M. (1987). Men and women of the corporation revisited. Management Review, 76(3), 14.

Karamanou, I., \& Vafeas, N. (2005). The association between corporate boards, audit committees, and management earnings forecasts: An empirical analysis. Journal of Accounting research, 43(3), 453-486.

Kassinis, G., Panayiotou, A., Dimou, A., \& Katsifaraki, G. (2016). Gender and environmental sustainability: A longitudinal analysis. Corporate Social Responsibility and Environmental Management, 23(6), 399-412.

Katmon, N., Mohamad, Z. Z., Norwani, N. M., \& Al Farooque, O. (2019). Comprehensive board diversity and quality of corporate social responsibility disclosure: evidence from an emerging market. Journal of Business Ethics, 157(2), 1-35.

Kessler-Harris, A. (1990). A new agenda for American Labor History: A gendered analysis and the question of class (pp. 217-234). The Problems of Synthesis.

Khan, H. (2010). The effect of corporate governance elements on corporate social responsibility (CSR) reporting. International Journal of Law and Management, 52(2), 82-109.

Kiliç, M., \& Kuzey, C. (2018). Determinants of forward-looking disclosures in integrated reporting. Managerial Auditing Journal, 33(1), 115-144.

Kimberly, J. R., \& Evanisko, M. J. (1981). Organizational innovation: The influence of individual, organizational and contextual fac-tors on hospital adoption of technological and administrative innovations. Academy of Management Journal, 24, 689-713.

Klein, A. (2002). Audit committee, board of director characteristics, and earnings management. Journal of Accounting and Economics, 33(3), 375-400.

Krippendorf, K. (1980). Content analysis: an introduction to its methodology. Beverly Hills Cal: SAGE Publications.

Lewis, B. W., Walls, J. L., \& Dowell, G. W. (2014). Difference in degrees: CEO characteristics and firm environmental disclosure. Strategic Management Journal, 35(5), 712-722.

Liao, L., Luo, L., \& Tang, Q. (2015). Gender diversity, board independence, environmental committee and greenhouse gas disclosure. The British Accounting Review, 47(4), 409-424.

Liao, Z., Zhang, M., \& Wang, X. (2019). Do female directors influence firms' environmental innovation? the moderating role of ownership type. Corporate Social-Responsibility and Environmental Management, 26(1), 257-263.

Lipton, M., \& Lorsh, J. W. (1992). A modest proposal for improved corporate governance. Business Lawyer, 48(1), 59-77.

Lipunga, A. M. (2015). Integrated reporting in developing countries: evidence from Malawi. Journal of Management Research, 7(3), 130-156.

Liu, S. (2015). Corporate governance and forward-looking disclosure: evidence from China. Journal of International Accounting, Auditing and Taxation, 25(2), 16-30.

Lorenzo, J. M. P., Sánchez, I. M. G., \& Gallego-Álvarez, I. (2009). Características del consejo de administración e información en materia de responsabilidad social corporativa. Revista Española de Financiación y Contabilidad, 38(141), 107-135. 
Makkonen, T., Williams, A. M., \& Habersetzer, A. (2018). Foreign board members and firm innovativeness: an exploratory analysis for setting a research agenda. Corporate Governance: The International Journal of Business in Society, 18(6), 1057-1073.

Manita, R., Bruna, M. G., Dang, R., \& Houanti, L. (2018). Board gender diversity and ESG disclosure: Evidence from the USA. Journal of Applied Accounting Research, 19(2), 206-224.

McGuinness, P. B., Vieito, J. P., \& Wang, M. (2017). The role of board gender and foreign ownership in the CSR performance of Chinese listed firms. Journal of Corporate Finance, 42, 75-99.

Melloni, G., Caglio, A., \& Perego, P. (2017). Saying more with less? Disclosure conciseness, completeness and balance in Integrated Reports. Journal of Accounting and Public Policy, 36(3), 220-238.

Melloni, G., Stacchezzini, R., \& Lai, A. (2016). The tone of business model disclosure: an impression management analysis of the integrated reports. Journal of Management and Governance, 20(2), 295-320.

Michelon, G., \& Parbonetti, A. (2012). The effect of corporate governance on sustainability disclosure. Journal of Management \& Governance, 16(3), 477-509.

Muttakin, M. B., \& Khan, A. (2014). Determinants of corporate social disclosure: Empirical evidence from Bangladesh. Accounting, incorporating Advances in International Accounting, 30, 168-175.

Muttakin, M. B., Khan, A., \& Subramaniam, N. (2015). Firm characteristics, board diversity and corporate social responsibility: evidence from Bangladesh. Pacific Accounting Review, 27(3), 353-372.

Nielsen, S., \& Huse, M. (2010). Women directors' contribution to board decision-making and strategic involvement: The role of equality perception. European Management Review, 7(1), 16-29.

O'Sullivan, M., Percy, M., \& Stewart, J. (2008). Australian evidence on corporate governance attributes and their association with forward-looking information in the annual report. Journal of Management and Governance, 12(1), 5-35.

Oppong, S. (2014). Upper echelons theory revisited: The need for a change from causal description to casual explanation. Management: journal of contemporary management issues, 19(2), 169-183.

Orazalin, N., \& Baydauletov, M. (2020). Corporate social responsibility strategy and corporate environmental and social performance: The moderating role of board gender diversity. Corporate Social -Responsibility and Environmental Management, 27(4), 1664-1676.

Park, K. M., \& Gould, A. M. (2017). The overlooked influence of personality, idiosyncrasy and eccentricity in corporate mergers and acquisitions: 120 years and six distinct waves. Journal of Management History, 23(1), 7-31.

Pearce, J. A., \& Zahra, S. A. (1992). Board composition from a strategic contingency perspective. Journal of Management Studies, 29, 411-438.

Perego, P., Kennedy, S., \& Whiteman, G. (2016). A lot of icing but little cake? Taking integrated reporting forward. Journal of cleaner production, 136, 53-64.

Perrini, F. (2006). The practitioner's perspective on non-financial reporting. California Management Review, 48(2), 73-103.

Pistoni, A., \& Songini, L. (2013). Corporate social responsibility determinants: The relation with CSR Disclosure (pp. 3-32). Bingley: Accounting and control for sustainability. Emerald Group Publishing Limited.

Pistoni, A., Songini, L., \& Bavagnoli, F. (2018). Integrated Reporting Quality: an Empirical Analysis. Corporate Social Responsibility and Environmental Management, 25, 489-507.

Pistoni, A., Songini, L., \& Perrone, O. (2016). The how and why of a firm's approach to CSR and sustainability: a case study of a large European company. Journal of Management and Governance, 20(3), 655-685.

Post, C., Rahman, N., \& McQuillen, C. (2015). From board composition to corporate environmental performance through sustainability-themed alliances. Journal of Business Ethics, 130(2), 423-435.

Post, C., Rahman, N., \& Rubow, E. (2011). Green Governance: Boards of Directors' Composition and Environmental Corporate Social Responsibility. Business \& Society, 50, 189-223.

Prado-Lorenzo, J. M., \& García-Sánchez, I. M. (2010). The role of the Board in disseminating relevant information on greenhouse gases. Journal of Business Ethics, 97, 391-424.

Qu, W., Ee, M. S., Liu, L., Wise, V., \& Carey, P. (2015). Corporate governance and quality of forwardlooking information: evidence from the Chinese stock market. Asian Review of Accounting, 23(1), 39-67.

Raimo, N., Vitolla, F., Marrone, A., \& Rubino, M. (2020). The role of ownership structure in integrated reporting policies. Business Strategy and the Environment. https://doi.org/10.1002/bse.2498

Raman, A. A., \& Bukair, A. A. (2013). The influence of the Shariah supervision board on corporate social responsibility disclosure by Islamic banks of Gulf Co-operation Council countries. AJBA, $6(2)$. 
Rao, K., \& Tilt, C. (2016). Board composition and corporate social responsibility: the role of diversity, gender, strategy and decision making. Journal of Business Ethics, 138(2), 327-347.

Ricart, J. E., Rodriguez, M. A., \& Sanchez, P. (2005). Sustainability in the boardroom: An empirical examination of Dow Jones sustainability world index leaders. Corporate Governance: The International Journal of Business in Society, 5(3), 24-41.

Richardson, A. J., \& Welker, M. (2001). Social disclosure, financial disclosure and the cost of equity capital. Accounting, organizations and society, 26(7-8), 597-616.

Rinaldi, L., Unerman, J., \& De Villiers, C. (2018). Evaluating the integrated reporting journey: insights, gaps and agendas for future research. Accounting, Auditing \& Accountability Journal, 31(5), 1294-1318.

Rogers, E. M., \& Shoemaker, P. (1971). Communication of innovations. Free Press.

Rudman, L. A., \& Glick, P. (2001). Prescriptive gender stereotypes and backlash toward agentic women. Journal of Social Issues, 57(4), 743-762.

Ruigrok, W., Peck, S., \& Tacheva, S. (2007). Nationality and gender diversity on Swiss corporate boards. Corporate Governance: An International Review, 15(4), 546-557.

Rupley, K. H., Brown, D., \& Marshall, S. (2012). Governance, media and the quality of environmental disclosure. Journal of Accounting and Public Policy, 31(6), 610-640.

Said, R., Zainuddin, Y. H., \& Haron, H. (2009). The Relationship Between Corporate Social Responsibility Disclosure and Corporate Governance Characteristics in Malaysian Public Listed Companies. Social Responsibility Journal, 5(2), 212-226.

Shahab, Y., Ntim, C. G., Chengang, Y., Ullah, F., \& Fosu, S. (2018). Environmental policy, environmental performance, and financial distress in China: Do top management team characteristics matter? Business Strategy and the Environment, 27(8), 1635-1652.

Shamil, M., Shaikh, M., \& J., Ho, P.L. and Krishnan, A. . (2014). The influence of board characteristics on sustainability reporting: empirical evidence from Sri Lankan firms. Asian Review of Accounting, 22(2), 78-97.

Songini, L., Pistoni, A., Bavagnoli, F., \& Minutiello, V. (2020). Integrated reporting quality: an analysis of key determinants, in Non-financial Performance. In L. Songini, A. Pistoni, P. Baret, \& M. Kunc (Eds.), Non-financial disclosure and integrated reporting: practices and critical issues (pp. 147-174). Emerald Group Publishing Limited, Howard House.

Sparrow, P. R. (1994). The Psychology of Strategic Management: Emerging Themes of Diversity and Cognition. In C. L. Cooper \& I. T. Robertson (Eds.), International Review of Industrial and Organizational Psychology (pp. 147-181). New Jersey: Wiley.

Stent, W., \& Dowler, T. (2015). Early assessments of the gap between integrated reporting and current corporate reporting. Meditari Accountancy Research, 23(1), 92-117.

Stubbs, W., \& Higgins, C. (2018). Stakeholders' Perspectives on the Role of Regulatory Reform in Integrated Reporting. Journal of Business Ethics, 147(3), 489-508.

Tamimi, N., \& Sebastianelli, R. (2017). Transparency among S\&P 500 companies: an analysis of ESG disclosure scores. Management Decision, 55(8), 1660-1680.

Uyar, A., \& Kiliç, M. (2012). Influence of corporate attributes on forward-looking information disclosure in publicly traded Turkish corporations. Procedia-Social and Behavioral Sciences, 62, 244-252.

Uyar, A., Kiliç, M., \& Nizamettin, B. (2014). Association between firm characteristics and corporate voluntary disclosure: evidence from Turkish listed companies. Intangible Capital, 9(4), 1080-1112.

Van der Walt, N., \& Ingley, C. (2003). Board dynamics and the influence of professional background, gender and ethnic diversity of directors. Corporate Governance: An International Review, 11(3), 218-234.

Velte, P., \& Stawinoga, M. (2017). Integrated reporting: The current state of empirical research, limitations and future research implications. Journal of Management Control, 28(3), 275-320.

Vitolla, F., Raimo, N., Marrone, A., \& Rubino, M. (2020b). The role of board of directors in intellectual capital disclosure after the advent of integrated reporting. Corporate Social Responsibility and Environmental Management. https://doi.org/10.1002/csr.1957

Vitolla, F., Raimo, N., \& Rubino, M. (2020a). Board characteristics and integrated reporting quality: an agency theory perspective. Corporate Social Responsibility and Environmental Management, 27(2), 1152-1163.

Vitolla, F., Raimo, N., Rubino, M., \& Garzoni, A. (2019a). How pressure from stakeholders affects integrated reporting quality. Corporate Social Responsibility and Environmental Management, 26(4), 1591-1606. 
Vitolla, F., Raimo, N., Rubino, M., \& Garzoni, A. (2019b). The impact of national culture on integrated reporting quality. A stakeholder theory approach. Business strategy and the environment, 28(8), 1558-1571.

Wang, J., \& Coffey, B. (1992). Board composition and corporate philanthropy. Journal of Business Ethics, 11(10), 771-778.

Wang, K., Sewon, O., \& Claiborne, M. C. (2008). Determinants and consequences of voluntary disclosure in an emerging market: evidence from China. Journal of International Accounting, Auditing and Taxation, 17, 14-30.

Wang, M., \& Hussainey, K. (2013). Voluntary forward-looking statements driven by corporate governance and their value relevance. Journal of Accounting and Public Policy, 32(3), 26-49.

Weber, R. P. (1990). Basic content analysis. Thousand Oaks, Cal: Sage.

Weir, C., \& Laing, D. (2003). Ownership structure, board composition and the market for corporate control in the UK: An empirical analysis. Applied Economics, 35, 1747-1759.

Westphal, J. D., \& Fredrickson, J. W. (2001). Who directs strategic change? Director experience, the selection of new CEOs, and change in corporate strategy. Strategic Management Journal, 22(12), 1113-1137.

Westphal, J. D., \& Milton, L. P. (2000). How Experience and Network Ties Affect the Influence of Demographic Minorities on Corporate Boards. Administrative Science Quarterly, 45(2), 336-398.

Williams, R. J. (2003). Women on corporate boards of directors and their influence on corporate philanthropy. Journal of Business Ethics, 42, 110.

Xie, B., Davidson, W. N., \& DaDalt, P. J. (2003). Earnings management and corporate governance: The role of the board and the audit committee. Journal of Corporate Finance, 9(3), 295-316.

Yasser, Q. R., Mamun, A. A., \& Rodrigs, M. (2017). Impact of board structure on firm performance: evidence from an emerging economy. Journal of Asia Business Studies, 11(2), 210-228.

Zhang, L., Shan, Y. G., \& Chang, M. (2020). Can CSR Disclosure Protect Firm Reputation During Financial Restatements? Journal of Business Ethics. https://doi.org/10.1007/s10551-020-04527-z

Publisher's Note Springer Nature remains neutral with regard to jurisdictional claims in published maps and institutional affiliations.

Lucrezia Songini Full Professor of Managerial Control Systems, Cost Management, Servitization Strategy and Strategic Management in Family Businesses, Eastern Piedmont University, Novara, Italy. Rector's Delegate for Third Mission and Social Impact, Director of the Linguistic Centre, Director of the Interuniversity Centre for Studies on Family Business, Eastern Piedmont University. SDA Professor of Accounting and Control, SDA Bocconi School of Management. European Academy of Management: Board member, Past-Chair of Entrepreneurship SIG. Her main research interest include: Strategic planning and control, performance measurement, cost management; Strategy, managerialization and professionalization of family businesses and SMEs; CSR and sustainability strategy, disclosure, performance measurement, reporting and control; Servitization strategy; Business models and digitalization. She is author of many books and articles.

Anna Pistoni Associate Professor of Managerial Control Systems at Insubria University (Varese) where she is Director of Master in General Management. She is also teacher of Managerial Accounting at Bocconi University (Milano). Her main research interests include: Sustainanability and performance measurement and communication, Integrated Reporting, Servitization strategies and Managerial Control, Mangerial Control and innovation processes. She is author of several international publications.

Patrizia Tettamanzi Associate Professor of International Financial Reporting, Strategic Management Accounting and Consolidated Financial Statements, Cattaneo University (LIUC), Castellanza, Italy. Adjunct Professor of Financial Reporting and Analysis, Bocconi University, Milan. She is scientific director of "Bilancio e Revisione" review. She is chartered accountant and auditor. Her main research interests include corporate social responsibility and sustainability, B-corp and benefit corporations, voluntary disclosure, accounting education. She is author of many books and articles. 
Fabrizio Fratini He works in Rome as a public service executive. He is Chartered Accountant and Auditor. His research interests include: corporate governance, integrated reporting, intellectual capital, public administration. He is author of some books and articles.

Valentina Minutiello Ph.D. student in Management, Finance, and Accounting at Cattaneo University (LIUC), Castellanza, Italy; teaching assistant for the courses of International Financial Reporting and Accounting and Financial Reporting. She is a Chartered Accountant. Her research interests include: corporate social responsibility and sustainability, voluntary disclosure, integrated and sustainability reporting, intellectual capital, family businesses and small and medium enterprises, accounting education. Author of some books and articles.

\title{
Authors and Affiliations
}

\section{Lucrezia Songini $^{1}$ (D) Anna Pistoni ${ }^{2} \cdot$ Patrizia Tettamanzi $^{3} \cdot$ Fabrizio Fratini $^{3}$. Valentina Minutiello ${ }^{3}$}

\author{
Anna Pistoni \\ anna.pistoni@uninsubria.it \\ Patrizia Tettamanzi \\ ptettamanzi@liuc.it \\ Fabrizio Fratini \\ myaddress2003@tiscali.it \\ Valentina Minutiello \\ vminutiello@liuc.it \\ 1 Department of Economics and Business, University of Eastern Piedmont, Via Perrone, 18, \\ 28100 Novara, NO, Italy \\ 2 Department of Economics, Insubria University, V. Monte Generoso, 71, 21100 Varese, Italy \\ 3 Libero Istituto Universitario C.Cattaneo, C.so Matteotti, 22, 21053 Castellanza, VA, Italy
}

